\title{
Some rare and interesting Conocybe found in Vyzhnytsia National Nature Park (Ukrainian Carpathians)
}

\section{Mykola P. Prydiuk}

Department of Mycology, M.G. Kholodny Institute of Botany, National Academy of Sciences of Ukraine, 2 Tereshchenkivska Str., 01001, Kiev, Ukraine (e-mail: prydiuk@gmail.com)

Received 6 September 2014 / Revised 4 November 2014 / Accepted 7 November 2014 / Published 26 November 2014

Prydiuk, M.P. 2014. Some rare and interesting Conocybe found in Vyzhnytsia National Nature Park (Ukrainian Carpathians). - Mycobiota 4: 1-24. doi: 10.12664/mycobiota.2014.04.01

\begin{abstract}
The data about some interesting representatives of the genus Conocybe found in Ukrainian Carpathians (Vyzhnytsia National Nature Park) are presented. A total of 14 taxa (including three varieties) were found. Four species and one variety new for this country (C. apala, C. inocybeoides, C. juniana var. sordescens, C. magnispora, and C. tuxlaensis) are reported, as well as some previously unknown localities for a further 9 taxa (C. echinata, C. hexagonospora, C. juniana var. subsejuncta, C. macrospora, C. pulchella, C. rostellata, C. siliginea, C. subpallida, and C. subxerophytica var. brunnea).
\end{abstract}

Key words: Bolbitiaceae, Conocybe, rare species, taxonomy, Ukraine, Ukrainian Carpathians

\section{Introduction}

The genus Conocybe and other representatives of the family Bolbitiaceae have rarely attracted attention of Ukrainian mycologists for a long time. As a rule the species of the genus could only be found in general lists of mushrooms of various regions of Ukraine (Bobyak 1907; Gizhhytska 1929; Pilát 1940; Ganzha 1960a, b; Wasser 1973, 1974; Wasser \& Soldatova 1977; Besedina 1998; Prydiuk 2003, 2005). Until recently only 6 species of the genus Conocybe were known in Ukraine: C. albipes (G.H. Otth) Hauskn., C. pilosella (Pers. : Fr.) Kühner, C. pubescens (Gillet) Kühner, C. rickeniana P.D. Orton, $C$. semiglobata Kühner \& Watling and C. tenera (Schaeff. : Fr.) Fayod. However, from 2003, some investigations with special attention to the genus were carried out. They lead to the discovery of a further 13 species of Conocybe for the Ukrainian mycota (Prydiuk 2007a, b). Further investigations are the subject of this paper. The specimens treated here were collected in Vyzhnytsia National Nature Park, founded in 1995 on the area of 7928.4 ha. 
It is located in Vyzhnytsia district of Chernivtsi region (Ukraine) and represents landscapes of the low-mountainous zone of the south-eastern part of the Ukrainian Carpathians. Its territory is mainly covered by forests (7546 ha) though some parts are occupied by meadows (155 ha) and swamps (10 ha). 56\% of forests are coniferous (mainly Abies alba Mill., less often Picea abies (L.) P. Karst.), a little less common are communities of Fagus sylvatica L. (42.3\%) (Chorney et al. 2005). Nevertheless most of the collected specimens of Conocybe were found in other habitats situated in small river valleys: meadows and moist forests composed of Alnus incana (L.) Moench.

\section{Matherials and methods}

This article is based on study collections made by the author during field work in 2013. Collected fruit bodies were dried as soon as possible using an electric dryer. The macroscopical descriptions were made on fresh material. The microscopic structures were observed in dried specimens. Microscopic sections of lamellae and pileipellis were made at about $1 / 2$ radius of the pileus and examined in $3 \% \mathrm{KOH}$. The spores were studied in water and $3 \% \mathrm{KOH}$ separately. Data on spore size are based on 20 spore measurements per fruit body from one habitat. For basidia and cystidia the mean of the smallest and the largest ones per fruit body is given with 10 measurements in each case. Ammoniacal reaction was investigated according to the protocol by Anton Hausknecht (Hausknecht 1999, 2009).

All collections mentioned in the paper are deposited in the Herbarium of the M.G. Kholodny Institute of Botany, National Academy of Sciences of Ukraine, Kiev, Ukraine $(\mathrm{KW})$.

In the descriptions of species the following abbreviations are used: av. $\mathrm{B}=$ average width of the spores in front view; av. $\mathrm{L}=$ average length of the spores; $\mathrm{L}=$ number of lamellae reaching stipe; $1=$ number of short lamellae (not reaching stipe) between two long ones; $\mathrm{Q}=$ length divided by width; av. $\mathrm{Q}=$ average $\mathrm{Q}$.

\section{Results and discussion}

A total of 14 taxa (including three varieties) of the genus Conocybe were collected in the park in 2013. New records for Ukraine were C. apala (Fr. : Fr.) Arnolds, C. inocybeoides Watling, C. juniana var. sordescens (P.D. Orton) Hauskn., C. magnispora (Murrill) Singer, and C. tuxlaensis Singer. The following 9 taxa were already known from Ukraine (C. echinata (Velen.) Singer, C. hexagonospora Hauskn. \& Enderle, C. juniana var. subsejuncta Hauskn., C. macrospora (G.F. Atk.) Hauskn., C. pulchella (Velen.) Hauskn. \& Svrček, C. rostellata (Velen.) Hauskn. \& Svrček, C. siliginea (Fr. : Fr.) Kühner, C. subpallida Enderle, and C. subxerophytica var. brunnea Hauskn.). Some of them (C. echinata, C. hexagonospora, C. juniana var. subsejuncta, C. pulchella, C. subpallida, and C. subxerophytica var. brunnea) were recorded from few locations and are apparently rare. The species are arranged according to the infrageneric system of Hausknecht \& KrisaiGreilhuber (2006). 
Genus Conocybe Fayod

Section Conocybe

Series Tenera Hauskn. \& Krisai

Conocybe subpallida Enderle, Z. Mykol. 57: 91, 1991.

Fig. 1

Pileus 10.0-30.0 mm, at first hemispherical, conical-campanulate or conical-convex, later convex, convex-applanate or conical-applanate, smooth or slightly radially-rugulose, pale yellow, light brownish orange, light greyish yellow, ochraceous or light yellow, darker at centre, ochraceous-brown, light brown or dark brownish, sometimes with slight olivaceousbrowh tinge, hygrophanous, not or indistinctly striate, on drying becoming pale ochraceous or pale greyish orange. Lamellae narrowly adnate or almost free, moderately distant ( $\mathrm{L}=$ 23-28, 1 = 3-7), ventricose, up to $3.0 \mathrm{~mm}$ wide, at first pale orange, later pale rust-brown, with paler finely flocculose edge. Stipe 50.0-85.0 × 1.5-5.0 mm, cylindrical, base bulbous, up to $6.0 \mathrm{~mm}$ broad, hollow, slightly longitudinally priunose-striate, at first whitish or pale yellowish, later brownish yellow or pale honey-brown, at base darker, to clay-brown. Flesh in pileus up to $1.5 \mathrm{~mm}$ broad, whitish with yellowish hue, in stipe pale brownish, at base clay-brownish. Taste and smell indistinct. Spore-print light rust-brown.

Spores (8.5-)9.0-11.5 $(-12.0) \times 5.0-6.5 \mu \mathrm{m}(\mathrm{n}=40), \mathrm{Q}=1.46-2.0$; av. $\mathrm{L}=10.3 \pm 0.79$ $\mu \mathrm{m}$, av. $\mathrm{B}=5.9 \pm 0.38 \mu \mathrm{m}$, av. $\mathrm{Q}=1.75 \pm 0.1$; in front view ellipsoid and narrowly-ellipsoid, in side view ellipsoid, flattened ventrally or slightly amygdaliform, germ-pore 1.5-2.0 $\mu \mathrm{m}$ wide, thin-walled, pale honey-yellow in water, pale yellowish brown or pale orange in alkali.

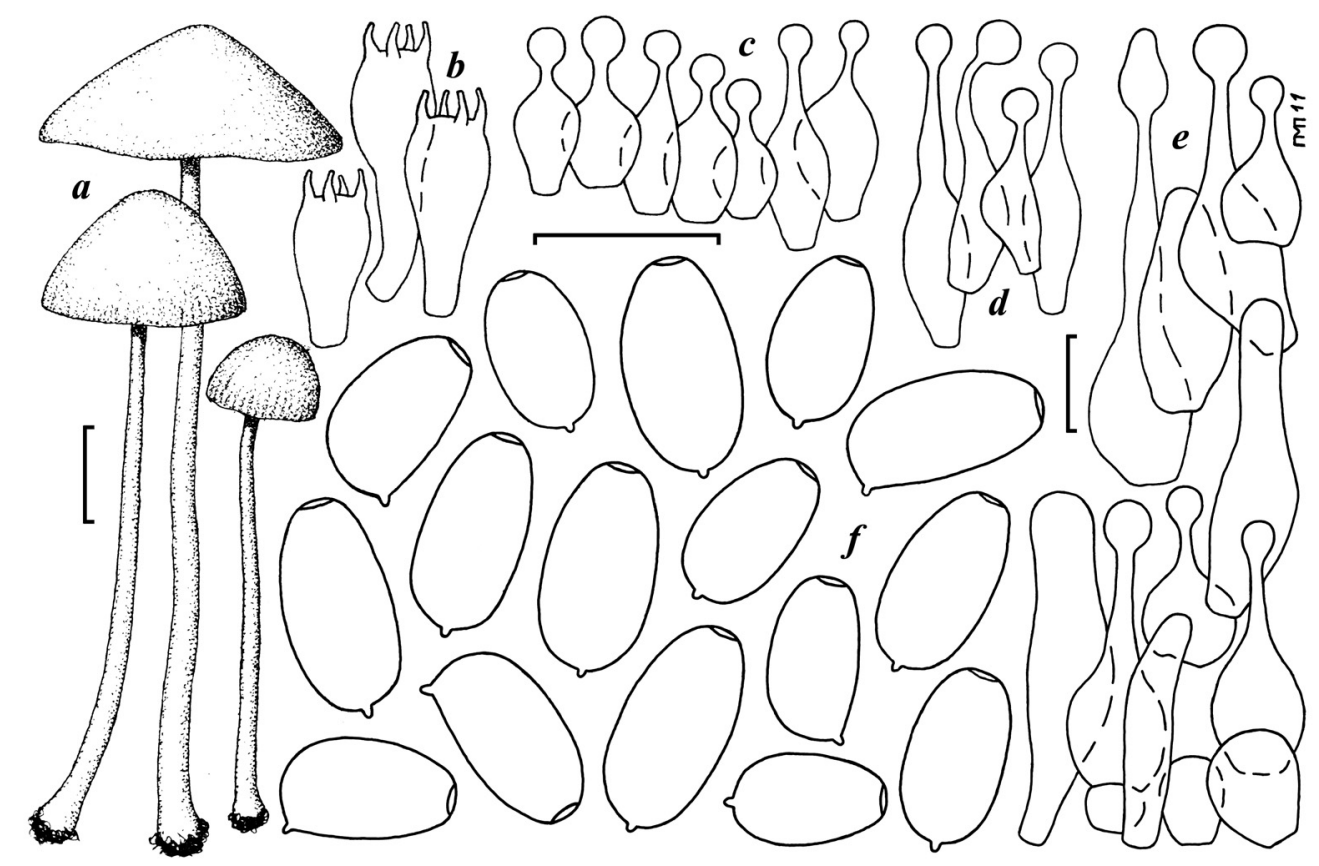

Fig. 1. Conocybe subpallida: $\mathbf{a}$ - fruit bodies, $\mathbf{b}$ - basidia, $\mathbf{c}$ - cheilocystidia, $\mathbf{d}$ - pileocystidia, $\mathrm{e}-$ caulocystidia, $\mathrm{f}$ - spores. Bars: $10 \mathrm{~mm}$ for fruit bodies, $10 \mu \mathrm{m}$ for microstructures 
Basidia 17.0-26.0 × 8.5-9.5 $\mu \mathrm{m}$, clavate, 4-spored. Cheilocystidia 15.0-19.0 × 6.0-8.5 $\mu \mathrm{m}$, lecythiform, neck up to $3.5 \times 1.5 \mu \mathrm{m}$, head $3.0-5.0 \mu \mathrm{m}$ wide. Pleurocystidia absent. Pileocystidia 20.0-35.0 $\times 6.0-8.0 \mu \mathrm{m}$, lecythiform, narrower than hymenial cystidia, neck up to $12.0 \times 2.0 \mu \mathrm{m}$, head $4.0-5.0 \mu \mathrm{m}$ wide, often with brownish walls, scattered or rather numerous. Caulocystidia mainly lecythiform, $16.0-48.0 \times 8.5-11.5 \mu \mathrm{m}$, neck up to 4.5$20.0 \times 2.0 \mu \mathrm{m}$, head 3.0-6.5 $\mu \mathrm{m}$ wide, with considerable admixture of globose and clavate elements up to $12.0 \times 9.5 \mu \mathrm{m}$, at stipe apex occuring some clavate and lageniform cells (up to $36.0 \times 9.5 \mu \mathrm{m}$ ) and few hairs (up to $80.0 \times 4.5 \mu \mathrm{m}$ ). Pileipellis hymeniform, consisting of sphaeropedunculate and pyriform elements 10.0-25.0 $\mu \mathrm{m}$ wide. Clamp connections present. Ammoniacal reaction usually positive and strong, sometimes detectable only after several hours.

Habitat and distribution. Solitary or in small groups on soil in deciduous forests, in autumn. In Ukraine apparently rare, earlier only known from two locations (Ternopil and Poltava regions). In Central Europe not rare (Hausknecht 2009).

Specimens examined: UKRAINE, CHERNIVTSI REGION, Vyzhnytsia district, Vyzhnytsia National Nature Park, the coast of the river Stebnyk, 48 $11^{\prime}$ N, $25^{\circ} 19^{\prime}$ E, alt. ca $450 \mathrm{~m}$, soil, 6 Sep 2013, M.P. Prydiuk (KW 50673); the coast of the river Vyzhenka, 48 $11^{\prime}$ N, $25^{\circ} 13^{\prime}$ E, alt. ca 450 m, soil, 9 Sep 2013, M.P. Prydiuk (KW 50735).

In some aspects (spore size, shape of cheilocystidia, positive ammoniacal reaction) Conocybe subpallida is similar to $C$. tenera, but differs by more thin-walled and paler spores, as well as paler pilei. Besides, its stipitipellis, particularly at stipe apex, has considerable admixture of non-lecythiform (clavate, lageniform and even hair-like) elements (Hausknecht 2000; Arnolds 2005). For this reason Enderle (1991) treated this species as belonging to the section Mixtae, but Hausknecht (2000) included C. subpallida in the section Conocybe because of its positive ammoniacal reaction, which was completely absent in representatives of the section Mixtae.

Conocybe subxerophytica var. brunnea Hauskn., Österr. Z. Pilzk. 11: 74, $2002 . \quad$ Fig. 2 Pileus $7.0-12.0 \mathrm{~mm}$, at first conical-convex, later convex, smooth or slightly radially rugulose, hygrophanous, not translucently striate, light rust-brown with reddish hue, on drying becoming orange-ochraceous or brownish ochraceous. Lamellae narrowly-adnate to almost free, rather crowded $(\mathrm{L}=18-25, \mathrm{l}=1-3)$, slightly ventricose, up to $1,5 \mathrm{~mm}$ wide, at first pale brown, later rust-brown, with paler finely flocculose edge. Stipe 40.0-50.0 × 0.7$1.0 \mathrm{~mm}$, cylindrical with clavate or slightly swollen base, hollow, pruinose, at first whitish or cream, later darkening to pale brown. Flesh in pileus and stipe yellowish to orange-white. Taste and smell indistinct. Spore-print not recorded.

Spores 9.5-12.5 $(-13.2) \times 6.5-8.0 \times 6.0-6.7 \mu \mathrm{m}(\mathrm{n}=20), \mathrm{Q}=1.43-1.85 ; \mathrm{av} . \mathrm{L}=$ $11.4 \pm 0.78 \mu \mathrm{m}$, av. $\mathrm{B}=7.2 \pm 0.46 \mu \mathrm{m}$, av. $\mathrm{Q}=1.59 \pm 0.09$; rather distinctly lentiform, in front view ovate to ellipsoid-ovate, in side view ellipsoid, slightly flattened ventrally or nearly amygdaliform, germ-pore central, up to $1.5 \mu \mathrm{m}$ wide, thick-walled, in water honey-brown, in alkali reddish brown. Basidia 15.0-23.0 × 8.0-11.5 $\mu \mathrm{m}$, clavate, 4-spored. Cheilocystidia $14.5-24.0 \times 6.0-9.5 \mu \mathrm{m}$, lecythiform, neck up to $2.5 \times 1.5 \mu \mathrm{m}$, head 3.0-5.0 $\mu \mathrm{m}$ wide.

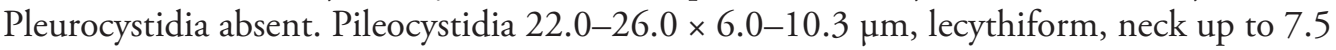




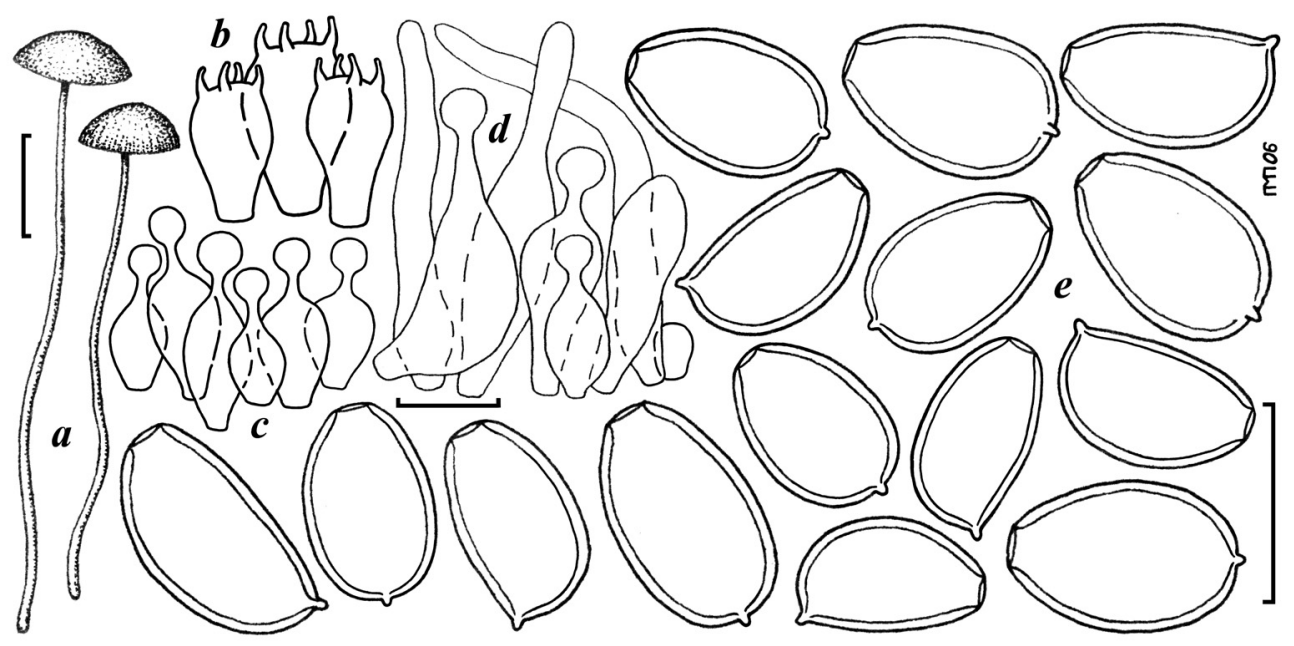

Fig. 2. Conocybe subxerophytica var. brunnea: $\mathbf{a}$ - fruit bodies, $\mathbf{b}$ - basidia, $\mathbf{c}$ - cheilocystidia, $\mathbf{d}$-caulocystidia, e - spores. Bars: $10 \mathrm{~mm}$ for fruit bodies, $10 \mu \mathrm{m}$ for microstructures

$\times 2.0 \mu \mathrm{m}$, head 3.0-4.5 $\mu \mathrm{m}$ wide, scattered. Caulocystidia mainly lecythiform 12.0-31.0 $\times 7.0-9.5 \mu \mathrm{m}$, neck up to $4.0 \times 2.0 \mu \mathrm{m}$, head 3.5-5.0 $\mu \mathrm{m}$ wide, near stipe apex present admixture of some clavate (up to $15.0 \times 7.0 \mu \mathrm{m}$ ), narrowly lageniform and cylindrical $(24.0-$ $43.0 \times 6.0-7.0 \mu \mathrm{m})$ elements. Pileipellis hymeniform, consisting of spheropedunculate and pyriform elements $10.0-25.0 \mu \mathrm{m}$ wide. Clamp connections present. Ammoniacal reaction negative.

Habitat and distribution. Solitary or in small groups on soil in grasslands (steppes, dry meadows and roadsides), from summer to autumn. Apparently rather rare in Ukraine, previously only known from one locality (Prydiuk 2007b), since 2008-2009 from two localities (Kiev and Odessa regions). Rare in Europe (Hausknecht 2009).

Specimen examined: UKRAINE, CHERNIVTSI REGION, Vyzhnytsia district, Vyzhnytsia National Nature Park, the coast of the river Stebnyk, $48^{\circ} 11^{\prime}$ N, $25^{\circ} 19^{\prime}$ E, alt. ca 450 m, soil, 6 Sep 2013, M.P. Prydiuk (KW 50736).

Conocybe subxerophytica var. subxerophytica is still unknown in Ukraine, and $C$. subxerophytica var. brunnea differs from it mainly by larger and darker fruit bodies with more crowded lamellae, as well as a slightly rugose pileus surface. Other representatives of the series Tenera being similar in some aspects to $C$. subxerophytica var. brunnea are C. semiglobata Kühner et Watling and $C$. dunensis T.J. Wallace, but their spores are not lentiform (Hausknecht 2009).

Series Magnicapitata Hauskn. \& Krisai

Conocybe echinata (Velen.) Singer, Fieldiana, Botany n.s. 21: 103, ('1987’)1989. Fig. 3 Galera echinata Velen., Novit. mycol. nov.: 69, 1947. - Conocybe spicula f. sordida Kühner, Genre Galera: 62, 1935. - Conocybe sordida Kühner et Watling in Watling, Notes. R. bot. Gdn. Edinb. 38: 339, 1980. 


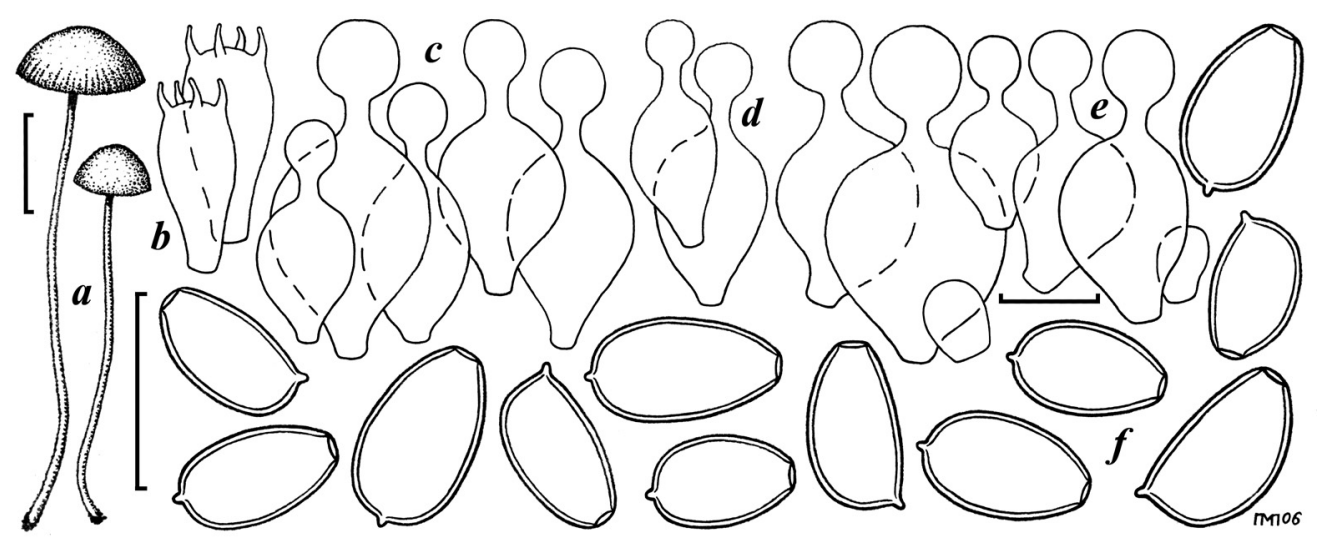

Fig. 3. Conocybe echinata: $\mathbf{a}$ - fruit bodies, b-basidia, c - cheilocystidia, d - pileocystidia, e-caulocystidia, $\mathbf{f}$ - spores. Bars: $10 \mathrm{~mm}$ for fruit bodies, $10 \mu \mathrm{m}$ for microstructures

Pileus 5.0-30.0 mm, at first hemispherical, later campanulate-convex, convex to planoconvex, with low umbo, smooth, hygrophanous, hardly translucently striate, at first dark brown, hazel-brown, greyish brown, dull brown, sometimes with purple or greyish violet tinge, towards margin paler, light brown, light greyish brown, brownish beige, often with paler radial stripes, on drying becoming pale coffee-brown or ochraceous-brown. Lamellae narrowly adnate to almost free, rather crowded $(\mathrm{L}=15-20,1=1-3(-7))$, ventricose, up to $3.0 \mathrm{~mm}$ wide, at first pale ochraceous, later ochraceous-brown to light rust-brown, with whitish finely flocculose edge. Stipe 30.0-75.0 × 1.0-3.0 mm, cylindrical, with clavate or slightly bulbous (up to $4.0 \mathrm{~mm}$ broad) base, hollow, pruinose to longitudinally pruinosestriate, at first pale yellow, pale ochraceous or pale yellowish brown with contrasting darker, browhish-orange, light brown, grey-brown or dark brown base, later becoming completely dull-brown to dark brown. Flesh in pileus up to $1.5 \mathrm{~mm}$ broad, pale yellowish to pale brownish yellow, in stipe darker, up to greyish brown. Taste and smell indistinct. Sporeprint light rust-brown.

Spores 7.5-10.0 $(-10.5) \times 4.5-5.5 \mu \mathrm{m}(\mathrm{n}=20), \mathrm{Q}=1.60-1.91$; av. Ls $=9.0 \pm 0.68$ $\mu \mathrm{m}$, av. $\mathrm{B}=5.2 \pm 0.25 \mu \mathrm{m}$, av. $\mathrm{Q}=1.74 \pm 0.07$; in front view ovate-ellipsoid, ellipsoid and narrowly ellipsoid, in side view ellipsoid, slightly flattened ventrally, sometimes slightly amygdaliform, germ pore central, up to $1.5 \mu \mathrm{m}$ wide, thin-walled, in water light yellow, in alkali light brown-yellow. Basidia 17.0-19.0 × 8.0-10.0 $\mu \mathrm{m}$, clavate, 4-spored. Cheilocystidia 22.0-33.5 × 11.0-17.0 $\mu \mathrm{m}$, lecythiform, neck up to $3.5 \times$ $2.5 \mu \mathrm{m}$, head 5.5-8.5 $\mu \mathrm{m}$ wide. Pleurocystidia absent. Pileocystidia 26.0-31.0 × 10.0$12.0 \mu \mathrm{m}$, lecythiform, somewhat narrower than cheilocystidia, neck up to $7.0 \times 2.5$ $\mu \mathrm{m}$, head 6.0-7.0 $\mu \mathrm{m}$ wide. Caulocystidia 22.0-33.5 × 9.5-19.0 $\mu \mathrm{m}$, lecythiform, neck up to $5.0 \times 2.5 \mu \mathrm{m}$, head (3.5-)5.0-9.5 $\mu \mathrm{m}$ wide, with admixture of globose and globose-clavate elements $12.0-12.5 \times 8.0-9.5 \mu \mathrm{m}$. Pileipellis hymeniform, consisting of spheropedunculate and pyriform elements 10.0-24.0 $\mu \mathrm{m}$ wide. Clamp connections present. Ammoniacal reaction negative. 
Habitat and distribution. Solitary or in small groups on soil in frondose forests, sometimes also in grasslands (meadows and pastures), in autumn. Apparently rare in Ukraine, earlier was known only from one location (Prydiuk 2007b), in 2007 it was found in the Nature reserve "Medobory" (Ternopil region). Rather frequent in Europe, also known from Asia (Siberia) (Hausknecht 2009).

Specimen examined: UKRAINE, CHERNIVTSI REGION, Vyzhnytsia district, Vyzhnytsia National Nature Park, near the river Stebnyk, $48^{\circ} 12^{\prime}$ N, $25^{\circ} 19^{\prime}$ E, alt. ca 450 m, soil, 6 Sep 2013, M.P. Prydiuk (KW 50672).

Conocybe echinata is microscopically very close to $C$. rickeniana P.D. Orton differing mainly by darker coloured pileus (dark-brown to greyish brown, sometimes even with purplish tinge) and contrasting darker stipe base (Hausknecht 1999). When herbarium material is in bad condition both species can be hardly separated from each other, and Arnolds (2005) suggested that C. echinata is only a variation of $C$. rickeniana.

Conocybe juniana var. sordescens (P.D. Orton) Hauskn., Österr. Z. Pilzk. 8: 50, 1999.

Fig. 4

Pileus 8.0-25.0 mm, at first hemispherical, later hemispherical-convex to conicalapplanate, smooth, at centre light reddish brown or dark clay-brown, at margin somewhat paler, to pale brown, hygrophanous, weakly translucently striate only at margin, striation quickly disappearing, on drying becoming cream or greyish cream. Lamellae narrowly adnate to almost free, moderately distant $(\mathrm{L}=17-23,1=1-3)$, slightly ventricose, up to $1.0 \mathrm{~mm}$ wide, at first pale clay-brown, later clay-brown, with concolorous hardly flocculose edge. Stipe 30.0-50.0 × 1.0-2.0 mm, cylindrical, base clavate, hollow, pruinose, at first pale cream, pale yellowish-brown, later darkening from base upwards to honey-brown. Flesh in pileus up to $1.0 \mathrm{~mm}$ wide, pale cream, in stipe somewhat darker. Taste and smell indistinct. Spore-print rust-brown.

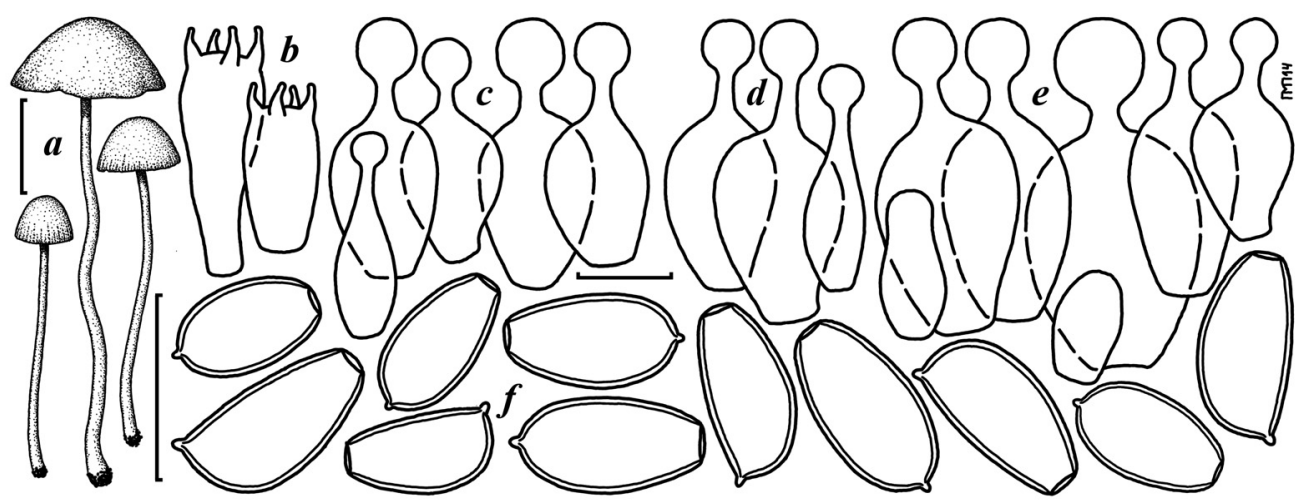

Fig. 4. Conocybe juniana var. sordescens: a - fruit bodies, $\mathbf{b}$ - basidia, c - cheilocystidia, dpileocystidia, e - caulocystidia, $\mathrm{f}$ - spores. Bars: $10 \mathrm{~mm}$ for fruit bodies, $10 \mu \mathrm{m}$ for microstructures 
Spores 8.0-10.5 × 4.5-5.5 $\mu \mathrm{m}(\mathrm{n}=20), \mathrm{Q}=1.67-2.22$; av. $\mathrm{L}=9.6 \pm 0.82 \mu \mathrm{m}$, av. $\mathrm{B}$ $=5.0 \pm 0.27 \mu \mathrm{m}$, av. $\mathrm{Q}=1.67 \pm 0.10$; in front view ovate to ovate-ellipsoid and ellipsoid, in side view ellipsoid, slightly flattened ventrally, sometimes slightly amygdaliform, germpore ca $1.0 \mu \mathrm{m}$ wide, thickwalled, brownish yellow in water, light reddish brown in alkali. Basidia 15.5-28.0 × 8.5-9.5 $\mu \mathrm{m}$, clavate, 4-spored. Cheilocystidia 19.0-29.0 × 7.0-12.0 $\mu \mathrm{m}$, lecythiform, neck up to $5.0 \times 2.0 \mu \mathrm{m}$, head 4.0-6.5(-7.0) $\mu \mathrm{m}$ wide. Pleurocystidia absent. Pileocystidia 24.0-32.0 × 7.0-14.5 $\mu \mathrm{m}$, lecythiform, neck up to $6.0 \times 2.0 \mu \mathrm{m}$, head 5.0-6.5 $\mu \mathrm{m}$ wide, usually fairly numerous. Caulocystidia mainly lecythiform, 24.0-38.0 $\times 11.0-20.0 \mu \mathrm{m}$, neck up to $5.0 \times 2.0 \mu \mathrm{m}$, head 5.0-9.5 $\mu \mathrm{m}$ wide, with inconsiderable admixture of globose, clavate and utriform elements up to $12.5 \times 6.0 \mu \mathrm{m}$. Pileipellis hymeniform, consisting of spheropedunculate and pyriform elements $16.0-40.0 \mu \mathrm{m}$ wide. Clamp connections present. Ammoniacal reaction negative.

Habitat and distribution. Solitary or in small groups on soil at forest edges, as well as in meadows and pastures, in autumn. In Ukraine apparently rare. In Europe rather rare (Hausknecht 2009).

Specimen examined: UKRAINE, CHERNIVTSI REGION, Vyzhnytsia district, Vyzhnytsia National Nature Park, near the river Stebnyk, $48^{\circ} 11^{\prime} \mathrm{N}, 25^{\circ} 19^{\prime}$ E, alt. ca 450 m, soil, 8 Sep 2013, M.P. Prydiuk (KW 50725).

Conocybe juniana (Velen.) Hauskn. \& Svrček var. juniana has not been found in Ukraine to-date. C. juniana var. sordescens differs from it by smaller spores and less voluminous cheiloand caulocystidia. On the other hand C. juniana var. subsejuncta has larger cheilo- and caulocystidia (with head up to $8.5 \mu \mathrm{m}$ wide) than C. juniana var. sordescens (Hausknecht 2009).

Conocybe juniana var. subsejuncta Hauskn., Österr. Z. Pilzk. 8: 52, 1999.

Fig. 5

Pileus $5.0-18.0 \mathrm{~mm}$, at first hemispherical, later conical, conical-convex to convex, smooth, brown, dirty brown or rust-brown, hygrophanous, translucently striate at margin, on drying becoming pale brown or pale ochraceous. Lamellae narrowly adnate to almost free, rather distant $(\mathrm{L}=15-20,1=1-3(-7))$, ventricose, up to $1.0 \mathrm{~mm}$ wide, at first ochraceousbrown, later light rust-brown, with concolorous hardly flocculose edge. Stipe 30.0-35.0 × 0.5-1.0 mm, cylindrical, with clavate base, hollow, pruinose, at first pale brown with whitish top, later becoming darker, light brown, at base brown. Flesh in pileus up to $0.7 \mathrm{~mm}$ wide, ochraceous, in stipe darker, brownish. Taste and smell indistinct. Spore-print rust-brown.

Spores 7.0-9.5 × 4.5-5.5 $\mu \mathrm{m}(\mathrm{n}=20), \mathrm{Q}=1.6-1.9$; av. $\mathrm{L}=8.6 \pm 0.75 \mu \mathrm{m}$, av. $\mathrm{B}$ $=5.0 \pm 0.32 \mu \mathrm{m}$, av. $\mathrm{Q}=1.71 \pm 0.08$; in front view ovate to ovate-ellipsoid, in side view ellipsoid, slightly flattened ventrally, germ-pore up to $1.5 \mu \mathrm{m}$ wide, thick-walled, brownish yellow in water, reddish brown in alkali. Basidia 19.0-22.0 × 8.0-9.0 $\mu \mathrm{m}$, clavate, 4-spored. Cheilocystidia 22.0-31.0 × 9.5-15.0 $\mu \mathrm{m}$, lecythiform, neck up to $5.0 \times 2.5 \mu \mathrm{m}$, head 5.0$8.5 \mu \mathrm{m}$ wide. Pleurocystidia absent. Pileocystidia 26.0-31.0 × 12.0-14.0 $\mathrm{mm}$, lecythiform, neck up to $6.0 \times 2.5 \mu \mathrm{m}$, head $5.0-6.0 \mu \mathrm{m}$ wide, usually fairly numerous. Caulocystidia mainly lecythiform, $19.0-34.0 \times 9.0-18.0 \mu \mathrm{m}$, neck up to $5.0 \times 2.5 \mu \mathrm{m}$, head 5.0-9.5 $\mu \mathrm{m}$ wide, sometimes with inconsiderable admixture of globose and cylindrical elements. Pileipellis hymeniform, consisting of sphaeropedunculate and pyriform elements 15.0$40.0 \mu \mathrm{m}$ wide. Clamp connections present. Ammoniacal reaction negative. 


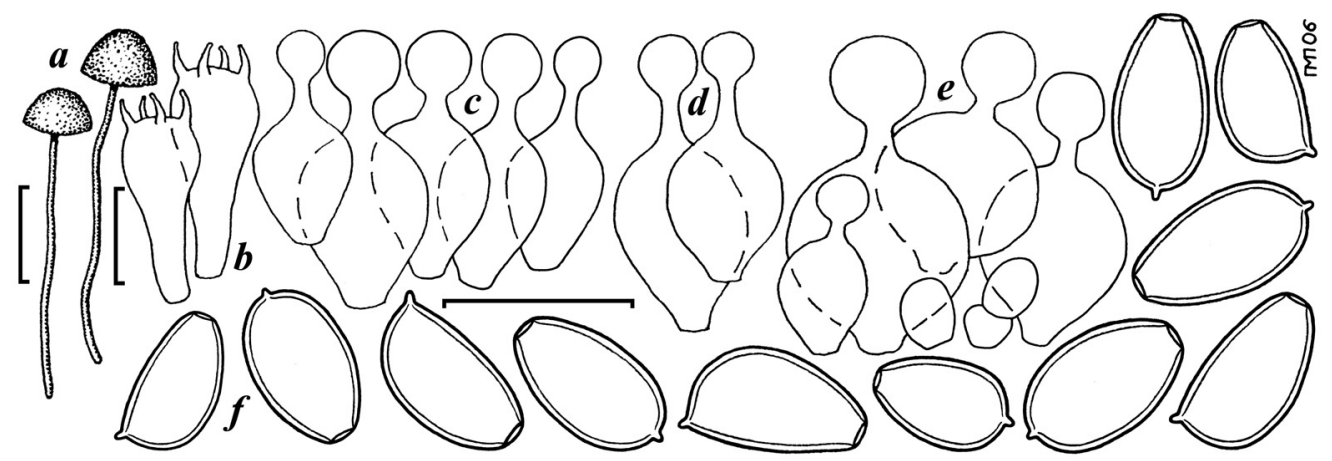

Fig. 5. Conocybe juniana var. subsejuncta: $\mathbf{a}$ - fruit bodies, $\mathbf{b}$ - basidia, $\mathbf{c}$ - cheilocystidia, $\mathrm{d}$ - pileocystidia, e - caulocystidia, $\mathrm{f}$ - spores. Bars: $10 \mathrm{~mm}$ for fruit bodies, $10 \mu \mathrm{m}$ for microstructures

Habitat and distribution. Solitary and in small groups on soil in meadows, as well as at forest margins, in autumn. In Ukraine apparently rare, earlier only known from one location (Prydiuk 2007b). In Europe rather rare, known in Asia (Tadjikistan, Georgia) (Hausknecht 2009)Specimen examined: UKRAINE, CHERNIVTSI REGION, Vyzhnytsia district, Vyzhnytsia National Nature Park, valley of the river Stebnyk, $48^{\circ} 11^{\prime} \mathrm{N}, 25^{\circ} 19^{\prime} \mathrm{E}$, alt. ca 450 m, soil, 6 Sep 2013, M.P. Prydiuk (KW 50726).

C. juniana var. subsejuncta differs from type variation by smaller not lentiform spores and more slender basidiocarps, while C. juniana var. sordescens can be distinguished by less voluminous cheilo- and caulocystidia.

\section{Section Mixtae Singer}

Subsection Ambiguae Hauskn. \& Krisai

Series Fragilis Hauskn. \& Krisai

Conocybe tuxlaensis Singer, Fieldiana, Botany n.s. 21: 105, 1989.

Fig. 6

Pileus $5.0-17.0 \mathrm{~mm}$, at first hemispherical, later hemispherical-convex to convex, smooth, brown, yellowish brown, ochraceous-brown, at centre dark brown or reddish brown, at margin paler, to ochraceous, hygrophanous, translucently striate up to $1 / 3$ radius, soon not striate, on drying becoming whitish. Lamellae narrowly adnate to almost free, moderately distant $(\mathrm{L}=15-20,1=1-3)$, slightly ventricose, up to $1.5 \mathrm{~mm}$ wide, at first pale brownish, later light rust-brown, with pale finely flocculose edge. Stipe $20.0-45.0 \times 1.0-2.0 \mathrm{~mm}$, cylindrical with slightly bulbous (up to $2.5 \mathrm{~mm}$ wide) base, hollow, slightly pubescent, whitish, later with yellowish hue. Flesh in pileus up to $0.5 \mathrm{~mm}$ wide, whitish, in stipe concolorous but slightly darker. Taste and smell indistinct. Spore-print light rust-brown.

Spores 5.5-7.2 × 3.0-4.0 $\mu \mathrm{m}, \mathrm{Q}=1.57-2.0$; av. $\mathrm{L}=6.1 \pm 0.43 \mu \mathrm{m}$, av. $\mathrm{B}=3.4 \pm 0.26$ $\mu \mathrm{m}$, av. $\mathrm{Q}=1.79 \pm 0.12$; in front view narrowly ovate, ovate-ellipsoid and ellipsoid, in face view ellipsoid, somewhat flattened ventrally or slightly amygdaliform, without germ-pore or with very indistinct one, thin-walled, pale yellowish in water, pale orange in alkali. Basidia 13.0-19.0 × 6.0-7.5 $\mu \mathrm{m}$, clavate, 4-spored. Cheilocystidia 14.5-19.0 × 6.0- 


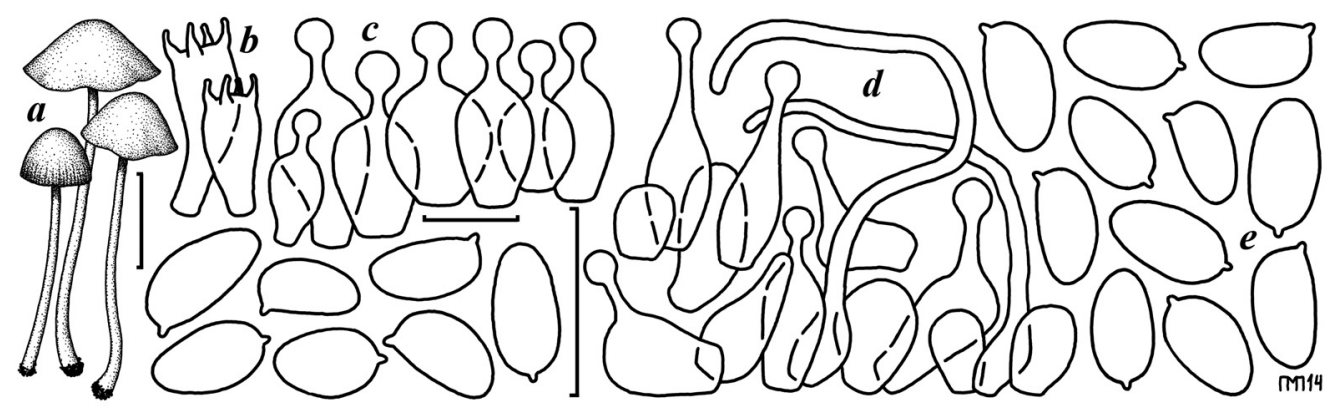

Fig. 6. Conocybe tuxlaensis: a - fruit bodies, $\mathbf{b}$ - basidia, c - cheilocystidia, d-caulocystidia, e-spores. Bars: $10 \mathrm{~mm}$ for fruit bodies, $10 \mu \mathrm{m}$ for microstructures

$11.5 \mu \mathrm{m}$, lecythiform, neck up to $2.5 \times 1.5 \mu \mathrm{m}$, head 3.0-4.5 $\mu \mathrm{m}$ wide. Pleurocystidia absent. Pileocystidia 15.5-22.0 $\times 4.0-8.5 \mu \mathrm{m}$, lecythiform, neck up to $6.5 \times 1.5 \mu \mathrm{m}$, head 3.0-4.5 $\mu \mathrm{m}$ wide, rather scarce. Caulocystidia of three types: a) 19.0-24.0 $\times 6.5$ $7.5 \mu \mathrm{m}$, lecythiform, neck up to $7.0 \times 1.5 \mu \mathrm{m}$, head 3.0-3.5 $\mu \mathrm{m}$ wide, numerous; b) 7.0 $14.5 \times 6.5-8.0 \mu \mathrm{m}$, ellipsoid, clavate and utriform, rather numerous; c) hair-like, up to $90.0 \times 2.0 \mu \mathrm{m}$, fairly rare. Pileipellis hymeniform, consisting of sphaeropedunculate and pyriform cells $15.0-19.0 \mu \mathrm{m}$ wide. Clamp connections present. Ammoniacal reaction negative.

Habitat and distribution. Solitary and in small groups on soil, in frondose forests, in autumn. In Ukraine apparently rare. In Europe rather rare, known also from Africa, North America and South America (Hausknecht 2009).

Specimen examined: UKRAINE, CHERNIVTSI REGION, Vyzhnytsia district, Vyzhnytsia National Nature Park, valley of the river Stebnyk, $48^{\circ} 12^{\prime}$ N, $25^{\circ} 18^{\prime}$ E, alt. ca 450 m, soil, 8 Sep 2013, M.P. Prydiuk (KW 50737).

Conocybe tuxlaensis is a rather remarkable representative of the section Mixtae. The small spores without germ-pore, stipitipellis consisting mainly of lecythiform cystidia and rather dark-coloured (though quickly pallescent after drying) pilei make the species rather easily identifiable. In many microscopical details (particularly by shape and size of spores) it is similar to C. pilosella but differs by structure of stipitipellis (presence of lecythiform caulocystidia).

Subsection Pubescens Hauskn. \& Krisai

Conocybe macrospora (G.F. Atk.) Hauskn., Österr. Z. Pilzk. 12: 64, 2003.

Fig. 7 Galerula macrospora G.F. Atk., Genus Galerula in North America: 371, 1918. - Conocybe pubescens var. macrospora (G.F. Atk.) E. Ludw., Pilzkompendium 2: 135, 2007. - Galera megalospora Jul. Schäff., Z. Pilzk. 9: 170, 1930 (p.p.), non Conocybe megalospora Singer, Lilloa 25: 297, 1953 (= C. pubescens). - Conocybe megalospora ssp. nivalis Singer, Rev. Mycol. Paris 18: 18, 1953. - Conocybe rubiginosa Watling, Notes. R. bot. Gdn. Edinb. 38: 353, 1980.

Pileus 5.0-30.0 mm, at first campanulate, later conical-campanulate to campanulateconvex, slightly pubescent, soon glabrous, hygrophanous, striate almost to centre, moist brown, rust-brown, light brown to orange-brown, at margin slightly paler, on drying 


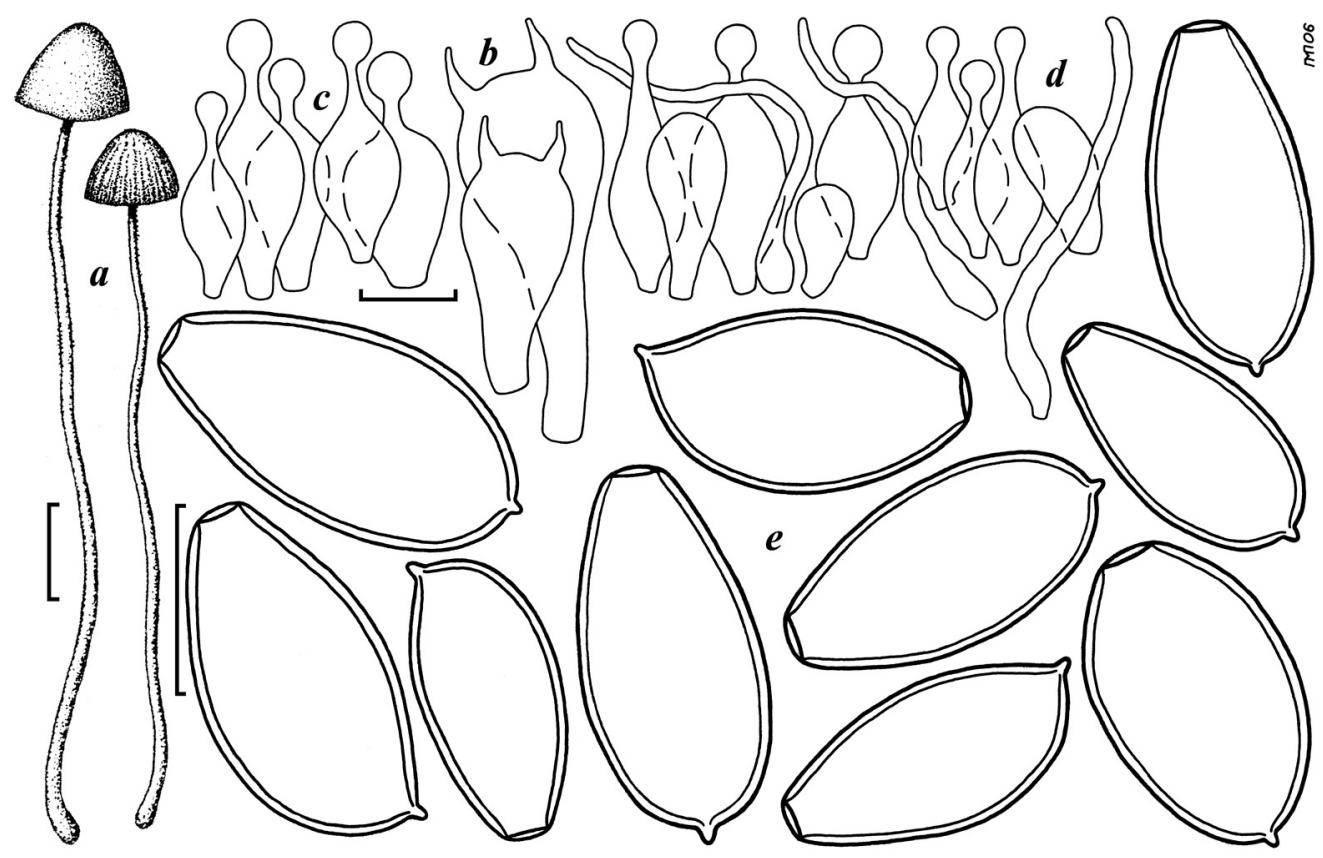

Fig. 7. Conocybe macrospora: a - fruit bodies, b- basidia, c-cheilocystidia, d - caulocystidia, e - spores. Bars: $10 \mathrm{~mm}$ for fruit bodies, $10 \mu \mathrm{m}$ for microstructures

becoming pale brownish orange, orange- to ochraceous-yellow, at margin paler. Lamellale narrowly adnate to almost free, rather crowded $(\mathrm{L}=15-25,1=1-3(-7))$, ventricose, up to $3.0 \mathrm{~mm}$ wide, at first pale brown, later light rust-brown to rust-brown, with paler finely flocculose edge. Stipe 50.0-95.0 × 1.0-3.0 mm, cylindrical with slightly or clearly bulbous base (up to $5.0 \mathrm{~mm}$ broad), hollow, longitudinally pruinose-striate, at apex pubescentpruinose, at first pale yellow in upper part, below darker, pale orange, to reddish brown at base, later light brownish-orange, honey-brown. Flesh in pileus up to $1.5 \mathrm{~mm}$ wide, whitish to pale yellowish, in stipe darker, to orange-yellow. Taste and smell indistinct, sometimes with slight radish odour. Spore-print rust-brown.

Spores (13.5-)16.0-19.0(-20.5) × (7.0-)8.0-10.5(-11.5) $\mu \mathrm{m}(\mathrm{n}=80), \mathrm{Q}=1.62-2.0$; av. $\mathrm{L}=18.0 \pm 1.28 \mu \mathrm{m}$, av. $\mathrm{B}=10.0 \pm 0.82 \mu \mathrm{m}$, av. $\mathrm{Q}=1.81 \pm 0.09$; in front view ellipsoid to slightly limoniform-ellipsoid, in side view ellipsoid, slightly flattened ventrally or somewhat amygdaliform, germ-pore central, up to $3.0 \mu \mathrm{m}$ wide, thick-walled, yellow-brown in water, reddish-brown in alkali. Basidia 17.0-23.0 × 11.0-12.0 $\mu \mathrm{m}$, clavate, 2-spored. Cheilocystidia 15.0-26.0 × 5.5-10.0 $\mu \mathrm{m}$, lecythiform, neck up to $3.5 \times 2.5 \mu \mathrm{m}$, head 3.0$5.0 \mu \mathrm{m}$ wide. Pleurocystidia absent. Pileocystidia cylindrical and hair-like, up to $85.0 \times 2.5$ $\mu \mathrm{m}$, scattered or rather numerous. Caulocystidia of three types: a) 15.0-22.0 $\times 6.0-10.0$ $\mu \mathrm{m}$, lecythiform, neck up to $4.0 \times 1.5 \mu \mathrm{m}$, head 3.0-5.0 $\mu \mathrm{m}$ wide; b) $9.0-16.0 \times 6.0-8.5$ $\mu \mathrm{m}$, ellipsoid, globose-clavate and clavate; c) hair-like, up to $100.0 \times 2.0 \mu \mathrm{m}$. Pileipellis hymeniform, consisting of spheropedunculate and pyriform elements 15.0-25.0 $\mu \mathrm{m}$ wide. Clamp connections present. Ammoniacal reaction negative. 
Habitat and distribution. Solitary or in scattered groups on soil, sometimes on manured soil or burnt places, in frondose, coniferous and mixed forests, as well as in grasslands (meadows, pastures, roadsides), in summer and autumn. In Ukraine apparently rather rare, at first only known from one location (Prydiuk 2007a), later found in another one (Volyn region). In Europe rather widerspread, known also from Asia, Africa, North and South America, and New Zealand (Hausknecht 2009).

Specimens examined: UKRAINE, CHERNIVTSI REGION, Vyzhnytsia district, Vyzhnytsia National Nature Park, valley of the river Stebnyk, $48^{\circ} 10^{\prime}$ N, $25^{\circ} 17^{\prime}$ E, alt. ca 450 m, soil, 6 Sep 2013, M.P. Prydiuk (KW 50740, 50741); valley of the river Lekeche, $48^{\circ} 07^{\prime} \mathrm{N}, 25^{\circ} 16^{\prime}$ E, alt. ca $450 \mathrm{~m}$, burnt ground, 7 Sep 2013, M.P. Prydiuk (KW 50727);

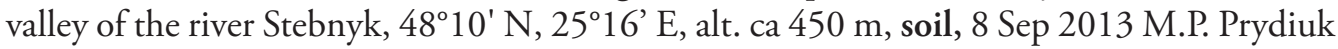
(KW 50728).

Due to its 2-spored basidia and very large thick-walled spores Conocybe macrospora is rather easily identificable. Other representatives of subsection Pubescens have a number of differences. For example, C. pubescens (Gillet) Kühner possesses similar fruit bodies but has slightly smaller spores and 4-spored basidia. C. pulchella (Velen.) Hauskn. et Svrček differs by more slender fruit bodies growing only on soil, as well as noticeably smaller spores and 4-spored basidia. Similarly growing on dung and possessing 2-spored basidia C. merdaria Arnolds et Hauskn. can be distinguished by considerably smaller spores (Hausknecht 2009).

Conocybe pulchella (Velen.) Hauskn. \& Svrček, in Hausknecht, Czech Mycol. 51: 58, 1999.

Fig. 8

Galera pulchella Velen., České Houby: 543, ('1920')1921. - Conocybe pubescens var. pseudopilosella Kühner, Genre Galera: 89, 1935. - Conocybe pseudopilosella (Kühner) Kühner \& Romagn., Fl. anal. Champ. sup.: 346, 1953. - Conocybe pseudopilosella Kühner \& Watling, in Watling, Notes. R. bot. Gdn. Edinb. 38: 336, 1980; non sensu Breitenb. \& Kränzl., Pilze Schweiz 4: 306, 1995. - Conocybe digitalina (Velen.) Singer, Fieldiana, Botany n.s. 21: 103, 1989.

Pileus $5.0-15.0 \mathrm{~cm}$, cap first campanulate or conical, later conical-convex, often slightly umbonate, hardly expanding, usually its height exceeds width, slightly pubescent, soon glabrous, orange-brown, light brown, rust-brown, at margin somewhat paler, hygrophanous, translucently striate almost to centre, on drying becoming light orange, pale orange or pale ochraceous-brown. Lamellae narrowly adnate to almost free, rather distant $(\mathrm{L}=20$ $25,1=1-3)$, ventricose, up to $2.5 \mathrm{~mm}$ wide, at first pale ochraceous, later orange-brown to rust-brown, with paler finely flocculose edge. Stipe $3.5-8.0 \times 0.1-0.25 \mathrm{~cm}$, cylindrical with slightly bulbous (up to $3.0 \mathrm{~mm}$ broad) base, hollow, slightly pruinose-striate, at first pale yellowish to ochraceous, later darkening from base upwards to light orange-brown, yellowbrown or brownish, at base to reddish brown. Flesh in pileus up to $1.5 \mathrm{~mm}$ wide, whitish to pale yellowish, in stipe orange-brown to reddish-brown. Taste and smell indistinct. Spore-print rust-brown.

Spores 12.0-16.0 $(-17.0) \times 7.0-9.5 \mu \mathrm{m}(\mathrm{n}=20), \mathrm{Q}=1.50-2.17$; av. $\mathrm{L}=14.6 \pm 1.13$ $\mu \mathrm{m}$, av. $\mathrm{B}=8.6 \pm 0.56 \mu \mathrm{m}$, av. $\mathrm{Q}=1.71 \pm 0.14$; in front view ovate-ellipsoid and ellipsoid, in side view ellipsoid, somewhat flattened ventrally to slightly amygdaliform, germ- 


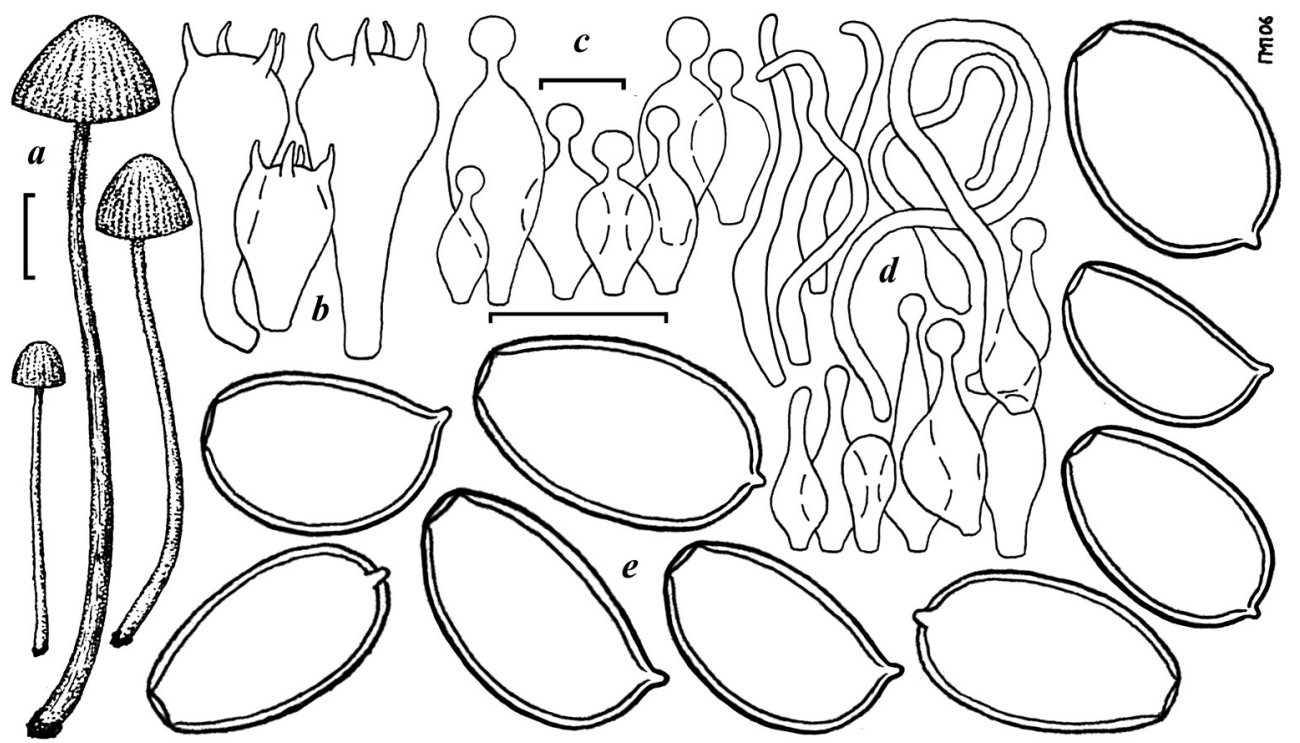

Fig. 8. Conocybe pulchella: a - fruit bodies, b-basidia, c - cheilocystidia, d - caulocystidia, e - spores. Bars: $10 \mathrm{~mm}$ for fruit bodies, $10 \mu \mathrm{m}$ for microstructures

pore up to $2.0 \mu \mathrm{m}$ wide, thick-walled. yellow-brown in water, rust- or reddish-brown in alkali. Basidia 17.0-31.0 × 10.0-15.5 $\mu \mathrm{m}$, clavate, 4-spored. Cheilocystidia 14.0$34.0 \times 6.0-10.0 \mu \mathrm{m}$, lecythiform, neck up to $4.5 \times 2.5 \mu \mathrm{m}$, head 3.0-5.0 $\mu \mathrm{m}$ wide. Pleurocystidia absent. Pileocystidia hair-like, up to $70.0 \times 2.0 \mu \mathrm{m}$, scattered or fairly numerous. Caulocystidia of three types: a) 12.0-27.0 × 5.0-10.0 $\mu \mathrm{m}$, lecythiform, neck up to $10.0 \times 2.0 \mu \mathrm{m}$, head 3.0-5.0 $\mu \mathrm{m}$ wide, rather numerous; b) $12.0-17.0 \times 5.5-7.5$ $\mu \mathrm{m}$, ellipsoid, globose-clavate, clavate and utriform, numerous; c) hair-like, up to 90.0 $\times 2.5 \mu \mathrm{m}$, fairly numerous. Pileipellis hymeniform, consisting of sphaeropedunculate and pyriform elements 10.0-24.0 $\mu \mathrm{m}$ wide. Clamp connections present. Ammoniacal reaction negative.

Habitat and distribution. Solitary or in small groups on soil, in grasslands (meadows, pastures, roadsides), in summer and autumn. In Ukraine rather rare, before known from three locations (Prydiuk 2007a). Widespread in Europe, occurs also in Asia (Siberia, Kamchatka) and Africa (Tanzania) (Hausknecht 2009).

Specimens exmined: UKRAINE, CHERNIVTSI REGION, Vyzhnytsia district, Vyzhnytsia National Nature Park, valley of the river Stebnyk, $48^{\circ} 11^{\prime} \mathrm{N}, 2^{\circ} 19^{\prime} \mathrm{E}$, alt. ca 450 m, soil, 6 Sep 2013, M.P. Prydiuk (KW 50730).

Conocybe pulchella is identificable by its rather slender fruit bodies with hardly expanding pileus and tall thin stipe, rather distant lamellae, large thick-walled spores and stipitipellis consisting of a mixture of lecytiform, non-lecythiform and hair-like elements. Rather close species $C$. pubescens and $C$. subpubescens P.D. Orton have larger basidiocarps with more expanding pileus. Besides, C. pubescens grows on dung and has larger spores, while C. subpubescens differs by somewhat smaller spores (Hausknecht 2003, 2009). 
Section Pilosellae Singer

Subsection Pilosellae

Series Inocybeoides Hauskn. \& Krisai

Conocybe apala (Fr. : Fr.) Arnolds, Persoonia 18: 225, 2003.

Fig. 9

Agaricus apalus Fr., Observ. Mycol. 2: 142, 1818. - Agaricus apalus Fr. : Fr., Syst. Mycol. 1: 265, 1821. - Pluteolus apalus (Fr. : Fr.) Quél., Enchir. Fung.: 105, 1886. - Agaricus sphaerobase Post : Fr., Monographia 2: 303, 1863. - Conocybe huijsmanii Watling, Nordic J. Bot. 3: 262, 1983. - Bolbitius huijsmanii (Watling) Bon, Doc. Mycol. 20/78: 39, 1990. Conocybe elegans Watling, Nordic J. Bot. 3: 263, 1983.

Pileus 10.0-45.0 mm, at first hemispherical or hemispherical-convex, later campanulate-convex to campanulate-applanate, slightly umbonate or not umbonate, somewhat pubescent, soon glabrous, in moist condition slightly glutinous, at first brown, yellowish brown, towards margin pale brown to greyish orange, hygrophanous, weakly translucently striate at margin, soon drying and becoming at first pale orange-grey, later yellowish white or whitish. Lamellae narrowly adnate to almost free, crowded $(\mathrm{L}=25-30,1=1-3(-7))$, ventricose, up to $3.0 \mathrm{~mm}$ wide, at first pale yellowish, later yellow-brown to rust-brown, with concolorous or slightly paler finely flocculose edge. Stipe $45.0-85.0 \times 2.0-4.0 \mathrm{~mm}$, slightly narrowing upwards, with bulbous base up to $7.0 \mathrm{~mm}$ wide, hollow, pruinosepubescent to slightly hairy, white, later whitish or with yellowish tinge. Flesh in pileus up

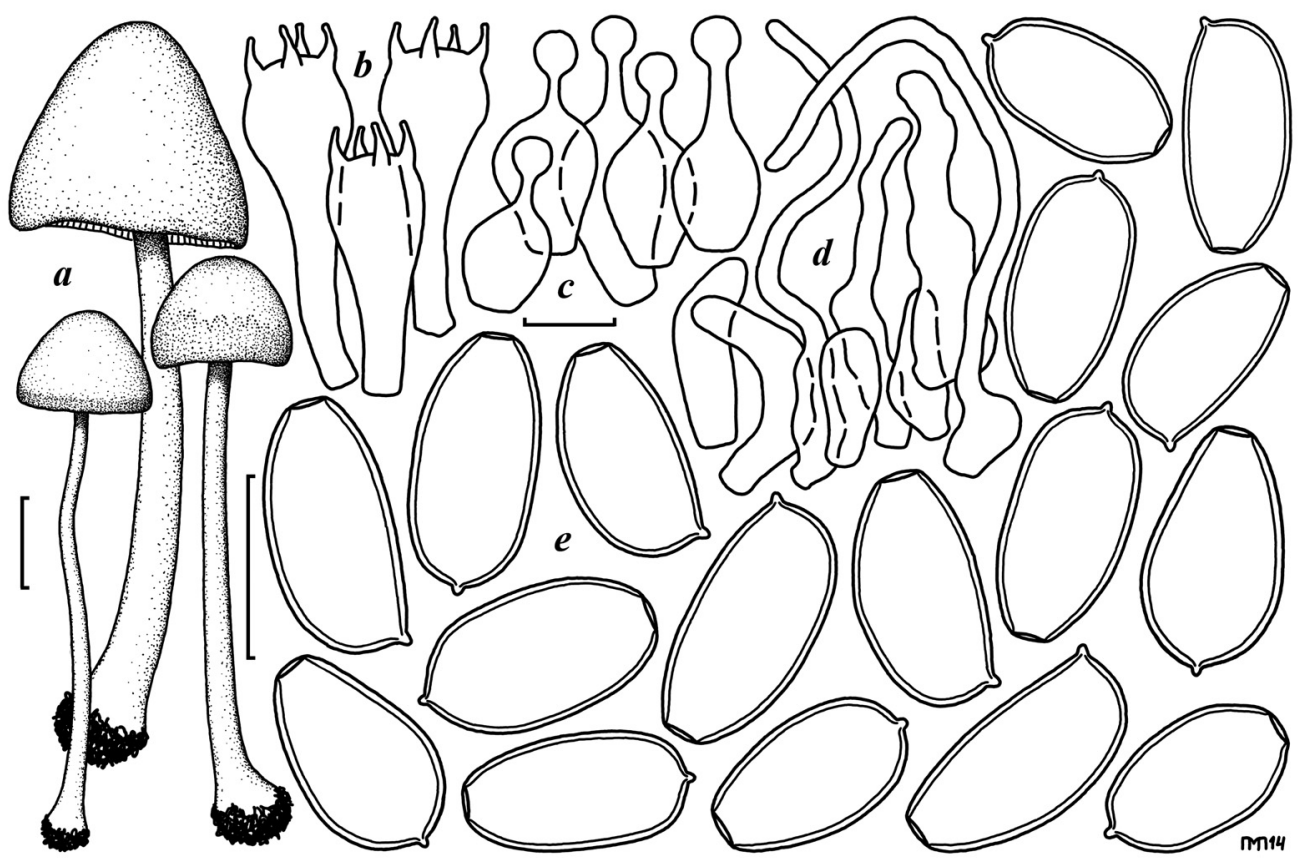

Fig. 9. Conocybe apala: $\mathbf{a}$ - fruit bodies, $\mathbf{b}$ - basidia, $\mathbf{c}$ - cheilocystidia, $\mathbf{d}$ - caulocystidia, e spores. Bars: $10 \mathrm{~mm}$ for fruit bodies, $10 \mu \mathrm{m}$ for microstructures 
to $2.0 \mathrm{~mm}$ wide, white, in stipe slightly darker, whitish with yellowish hue. Taste and smell indistinct. Spore-print rust-brown.

Spores 11.0-13.5(-14.0) × 6.0-7.0 $\mu \mathrm{m}(\mathrm{n}=20), \mathrm{Q}=1.57-2.03$; av. $\mathrm{L}=12.3 \pm 0.94$ $\mu \mathrm{m}$, av. $\mathrm{B}=6.8 \pm 0.39 \mu \mathrm{m}$, av. $\mathrm{Q}=1.80 \pm 0.14$; in front view narrowly-ovate, ovate-ellipsoid and ellipsoid, in side view ellipsoid, slightly flattened ventrally, germ-pore up to $2.5 \mu \mathrm{m}$ wide, thick-walled, pale honey-brown in water, yellowish or reddish brown in alkali. Basidia 26.0-36.0 × 10.5-12.0 $\mu \mathrm{m}$, clavate, 4-spored. Pseudoparaphyses absent. Cheilocystidia 19.0-31.0 × 8.5-11.5 $\mu \mathrm{m}$, lecythiform, neck up to $5.0 \times 1.5 \mu \mathrm{m}$, head 4.0-5.0 $\mu \mathrm{m}$ wide. Pleurocystidia absent. Pileocystidia hair-like, up to $70.0 \times 2.0 \mu \mathrm{m}$, scattered. Caulocystidia of two types: a) 14.5-34.0 ×5.5-8.0 $\mu \mathrm{m}$, globose-clavate, clavate, utriform and lageniform, numerous; b) hair-like, up to $85.0 \times 2.0 \mu \mathrm{m}$, rather rare. Pileipellis hymeniform, consisting of sphaeropedunculate and pyriform cells 15.0-30.0 $\mu \mathrm{m}$ wide. Clamp connections present. Ammoniacal reaction negative.

Habitat and distribution. Solitary and in small groups on grassy forest edges and meadows, in autumn. In Ukraine apparently rare. In Europe more frequent in northern countries (Hausknecht 2009).

Specimen examined: UKRAINE, CHERNIVTSI REGION, Vyzhnytsia district, Vyzhnytsia National Nature Park, near the river Stebnyk, $48^{\circ} 12^{\prime}$ N, $25^{\circ} 18^{\prime}$ E, alt. ca 450 m, soil, 6 Sep 2013, M.P. Prydiuk (KW 50722).

Dry fruit bodies of Conocybe apala are rather similar and colours to $C$. albipes, but $C$. apala can be distinguished by absence pseudoparaphyses and narrower spores. Another, in many aspects similar species is $C$. inocybeoides Watling, which has similarly large basidiocarps but differs by a brighter pileus (light brown or clay-brown, never being whitish), 2-spored basidia, as well as larger and broader spores (Hausknecht 2009).

Conocybe inocybeoides Watling, Notes R. bot. Gdn. Edinb. 38: 350, 1980.

Fig. 10 Galera bulbifera f. bispora Romagn., Bull. Soc. Mycol. France 58: 147, 1944. - Conocybe bulbifera (Kauffman) Romagn. sensu Arnolds in Arnolds et al., Overz. Paddest. Nederland: 105, 1995.

Pileus $10.0-40.0 \mathrm{~mm}$, at first campanulate or conical, later campanulate-applanate to convex-applanate, usually somewhat umbonate, slightly pubescent, soon glabrous, at first dark reddish brown, dark brown or rust-brown, later light brown clay- or ochraceous-brown, hygrophanous, not translucently striate, on drying becoming yellowish brown or pale coffeebrown. Lamellae narrowly adnate or almost free, moderately distant to rather distant $(\mathrm{L}=19-$ $25,1=1-3)$, ventricose, up to $4.0 \mathrm{~mm}$ wide, at first pale brown, later clay-brown to rubiginous, wuth concolorous finely flocculose edge. Stipe $40.0-80.0 \times 2.0-6.0 \mathrm{~mm}$, slightly narrowing upwards, with bulbous or nearly marginate base up to $10.0 \mathrm{~mm}$ broad, hollow, longitudinally pruinose- or pubescent-striate, at first white or whitish, later pale ochraceous-brown or pale yellowish-brown. Flesh in pileus up to $2.0 \mathrm{~mm}$ wide, whitish or pale ochraceous, in stipe pale brownish-ochraceous. Taste and smell indistinct. Spore-print rust-brown.

Spores 11.5-16.5(-17.0) $\times 6.5-10.5 \mu \mathrm{m}, \mathrm{Q}=1.49-1.81 ;$ av. $\mathrm{L}=14.5 \pm 1.5 \mu \mathrm{m}$, av. $B=8.7 \pm 0.94 \mu \mathrm{m}$, av. $Q=1.67 \pm 0.10$; in front view narrowly ovate, ovate-ellipsoid and ellipsoid, in side view ellipsoid, slightly flattened ventrally, germ-pore up to $2.5 \mu \mathrm{m}$ 


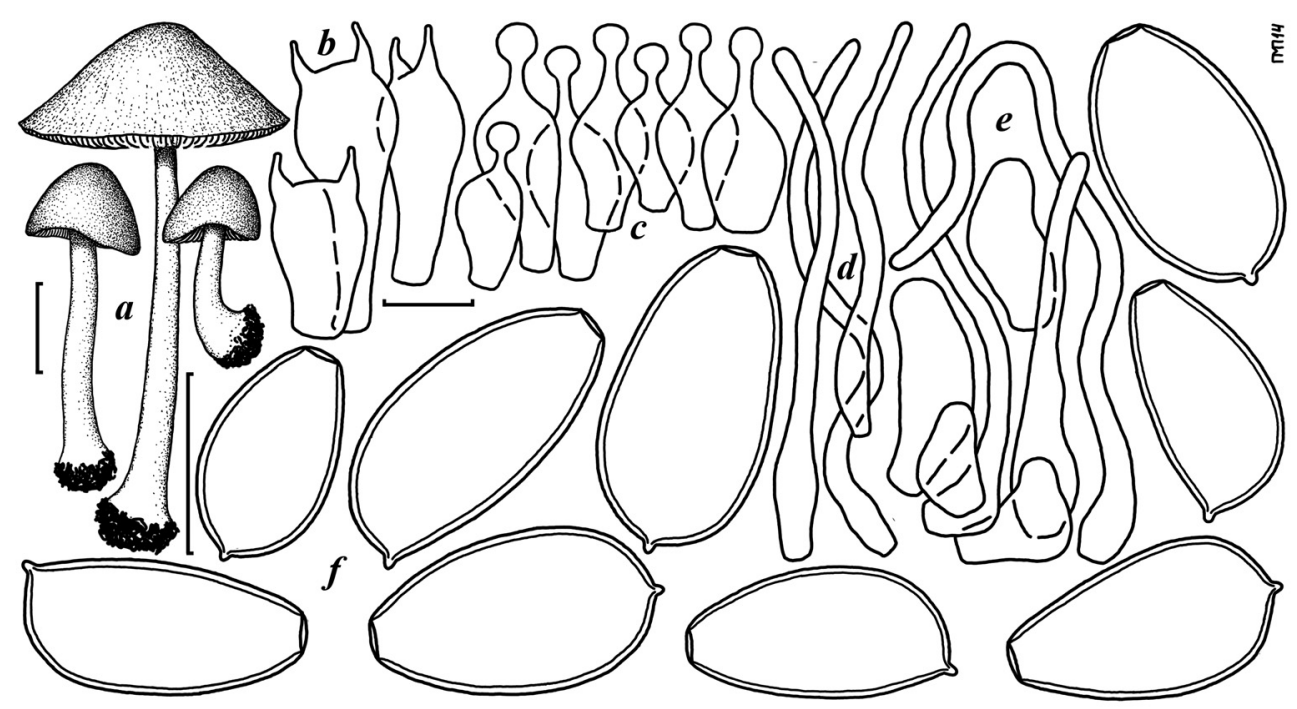

Fig. 10. Conocybe inocybeoides: $\mathbf{a}$ - fruit bodies, $\mathbf{b}$ - basidia, $\mathbf{c}$ - cheilocystidia, $\mathbf{d}$ - pileocystidia, $\mathrm{e}-$ caulocystidia, $\mathrm{f}$ - spores. Bars: $10 \mathrm{~mm}$ for fruit bodies, $10 \mu \mathrm{m}$ for microstructures

wide, thick-walled, pale honey brownish in water, brownish or brownish orange in alkali. Basidia 17.0-29.0 × 9.5-11.5 $\mathrm{m}$, clavate, 2-spored. Cheilocystidia 18.0-25.0 × 7.0$11.0 \mu \mathrm{m}$, lecythiform, neck up to $4.5 \times 2.0 \mu \mathrm{m}$, head 3.0-4.5 $\mu \mathrm{m}$ wide. Pleurocystidia absent. Pileocystidia narrowly-cylindrical to hair-like, up to $80.0 \times 2.0-4.5 \mu \mathrm{m}$, numerous. Caulocystidia of two types: a) $9.0-22.0 \times 6.5-10.0 \mu \mathrm{m}$, globose-clavate, clavate, utriform and lageniform; b) hair-like, up to $95.0 \times 2.0 \mu \mathrm{m}$. Pileipellis hymeniform, consisting of sphaeropedunculate and pyriform cells $15.0-23.0 \mu \mathrm{m}$ wide. Clamp connections present. Ammoniacal reaction negative.

Habitat and distribution. Solitary or in small groups on soil, in frondose forests and grasslands (meadows, pastures, roadsides), in autumn. In Ukraine apparently rare. In Europe rare (Hausknecht 2009).

Specimen examined: UKRAINE, CHERNIVTSI REGION, Vyzhnytsia district, Vyzhnytsia National Nature Park, valley of the river Stebnyk, $48^{\circ} 11^{\prime} \mathrm{N}, 25^{\circ} 19^{\prime}$ E, alt. ca 450 m, soil, 6 Sep 2013, M.P. Prydiuk (KW 50723).

The large basidiocarps and 2-spored basidia make C. inocybeoides rather distinguishable. Similarly massive fruit bodies has C. apala, which differs by paler (particularly in dry condition) pileus, 4-spored basidia and narrower somewhat smaller spores (Hausknecht 2009).

Series Sienophylla Hauskn. \& Krisai

Conocybe rostellata (Velen.) Hauskn. \& Svrček, in Hausknecht, Czech Mycol. 51: 61, 1999.

Galera rostellata Velen., Novit. mycol.: 129, ('1939')1940. - Conocybe siliginea var. ochracea 'récoltes microspores' Kühner, Genre Galera: 101, 1935. - Conocybe siliginea sensu Chrispijn, Champ. Jordaan: 67, 1999. 


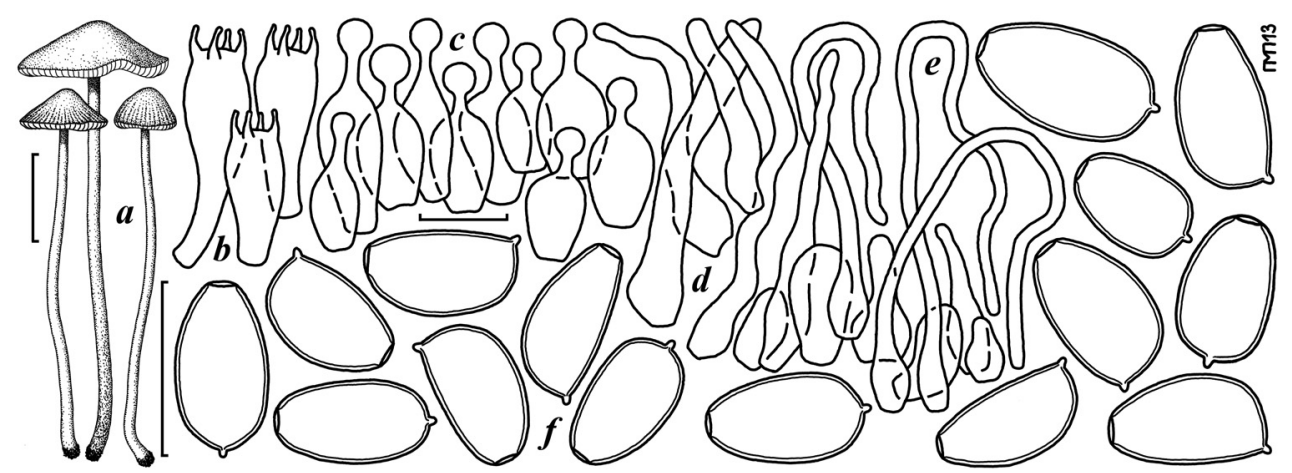

Fig. 11. Conocybe rostellata: a - fruit bodies, b - basidia, c - cheilocystidia, d - pileocystidia, e-caulocystidia, $\mathbf{f}$ - spores. Bars: $10 \mathrm{~mm}$ for fruit bodies, $10 \mu \mathrm{m}$ for microstructures

Pileus $5.0-20.0 \mathrm{~mm}$, at first conical-campanulate to almost hemispherical, later conical-convex, conical-applanate to plano-convex, sometimes slightly umbonate, smooth, ochraceous-brown, yellowish brown to light brown, paler at margins, hygrophanous, translucently striate up to $1 / 2$ radius and more, on drying becoming light ochraceous to greyish ochraceous. Lamellae narrowly-adnate to almost free, rather distant ( $\mathrm{L}=17-20,1=1-3)$, ventricose, up to $2.0 \mathrm{~mm}$ wide, at first pale ochraceous, later ochraceous-brown to rust-brown, with concolorous finely flocculose edge. Stipe $30.0-55.0 \times 1.0-2.0 \mathrm{~mm}$, cylindrical with clavate, often slightly swollen (up to 3.0 $\mathrm{mm}$ ) base, hollow, longitudinally pubescent-striate, at first whitish or pale ochraceous, later darkening from base upwards to pale brown or light brown, at base up to reddishbrown. Flesh in pileus up to $1.5 \mathrm{~mm}$ broad, whitish with ochraceous-brown tinge, in stipe darker, pale brownish, at base up to light reddish-brown. Taste and smell indistinct. Spore-print rust-brown.

Spores 7.0-9.0 × 4.5-5.5 $\mu \mathrm{m}(\mathrm{n}=40), \mathrm{Q}=1.44-1.70 ;$ av. $\mathrm{Ls}=8.2 \pm 0.59 \mu \mathrm{m}$, av. $\mathrm{B}$ $=5.2 \pm 0.32 \mu \mathrm{m}$, av. $\mathrm{Q}=1.57 \pm 0.06$; in front view ellipsoid-ovate, narrowly ellipsoid and ellipsoid, in side view ellipsoid, slightly flattened ventrally, sometimes nearly amygdaloid, germ-pore central, up to 1.0-1.5 $\mu$ m wide, rather thin-walled, pale brownish yellow in water, yellow-brown in alkali. Basidia 15.0-24.0 × 6.0-8.0 $\mu \mathrm{m}$, clavate, 4-spored. Cheilocystidia 17.0-21.0 × 6.5-7.5 $\mu \mathrm{m}$, lecythiform, neck up to $3.5 \times 2.0 \mu \mathrm{m}$, head 3.5-4.5 $\mu \mathrm{m}$ wide. Pleurocystidia absent. Pileocystidia hair-like, up to $36.0 \times 2.5-4.0 \mu \mathrm{m}$, rather numerous. Caulocystidia of two types: a) ellipsoid, globose-clavate, clavate, utriform and lageniform,

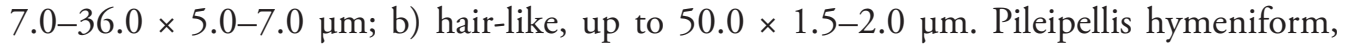
consisting of spheropedunculate and pyriform elements 10.0-35.0 $\mu \mathrm{m}$ wide. Clamp connections present. Ammoniacal reaction negative.

Habitat and distribution. Solitary or in small groups on soil, mainly in grasslands (meadows, pastures, from spring to autumn. In Ukraine apparently rare, only known from two locations (Ternopil and Odessa regions). In Central Europe rather common, known also from Africa, Asia, North and South America (Hausknecht \& Krisai-Greilhuber 2006; Hausknecht 2009). 
Specimens examined: UKRAINE, CHERNIVTSI REGION, Vyzhnytsia district, Vyzhnytsia National Nature Park, valley of the river Lekeche, $48^{\circ} 07^{\prime} \mathrm{N}, 25^{\circ} 16^{\prime} \mathrm{E}$, alt. ca 450 m, soil, 7 Sep 2013, M.P. Prydiuk (KW 50731, 50732).

Conocybe rostellata is rather close to C. ochrostriata Hauskn. and C. velutipes (Velen.) Hauskn. \& Svrček, but differs from both species by smaller and more thin-walled spores (moreover, spores of $C$. velutipes are rather distinctly lentiform). Besides, C. ochrostriata has larger and more robust fruit bodies (Hausknecht 2009). All specimens collected in Ukraine (including those treated in this paper) have slightly smaller spores than is indicated for $C$. rostellata (Hausknecht 2009). In this aspect they are fairly similar to C. pallidospora Kühner $\&$ Watling or C. pilosella (Pers. : Fr.) Kühner. However, the spores of both these species are distinctly paler, more thin-walled and have no germ-pore (or very weakly developed one), while spores of the examined specimens are rather thick-walled and with distinctl germpore. It allows to identify them as $C$. rostellata.

Subsection Siligineae Hauskn. \& Krisai

Series Murinacea Hauskn. \& Krisai

Conocybe magnispora (Murrill) Singer, Sydowia 4: 135, 1950.

Fig. 12

Galerula magnispora Murrill, Mycologia 35: 530, 1943.

Pileus 4.0-15.0 mm, at first campanulate or conical-campanulate, later hemispherical, slightly pubescent, soon glabrous, at first orange-brown or yellowish brown, later greyish ochraceous-brown, at margin paler, hygrophanous, transclucently striate to $1 / 2$ radius and more, on drying becoming pale ochraceous. Lamellae narrowly adnate to nearly free, rather crowded $(\mathrm{L}=23-28,1=1-3)$, ventricose, up to $1.5 \mathrm{~mm}$ wide, at first ochraceous, later

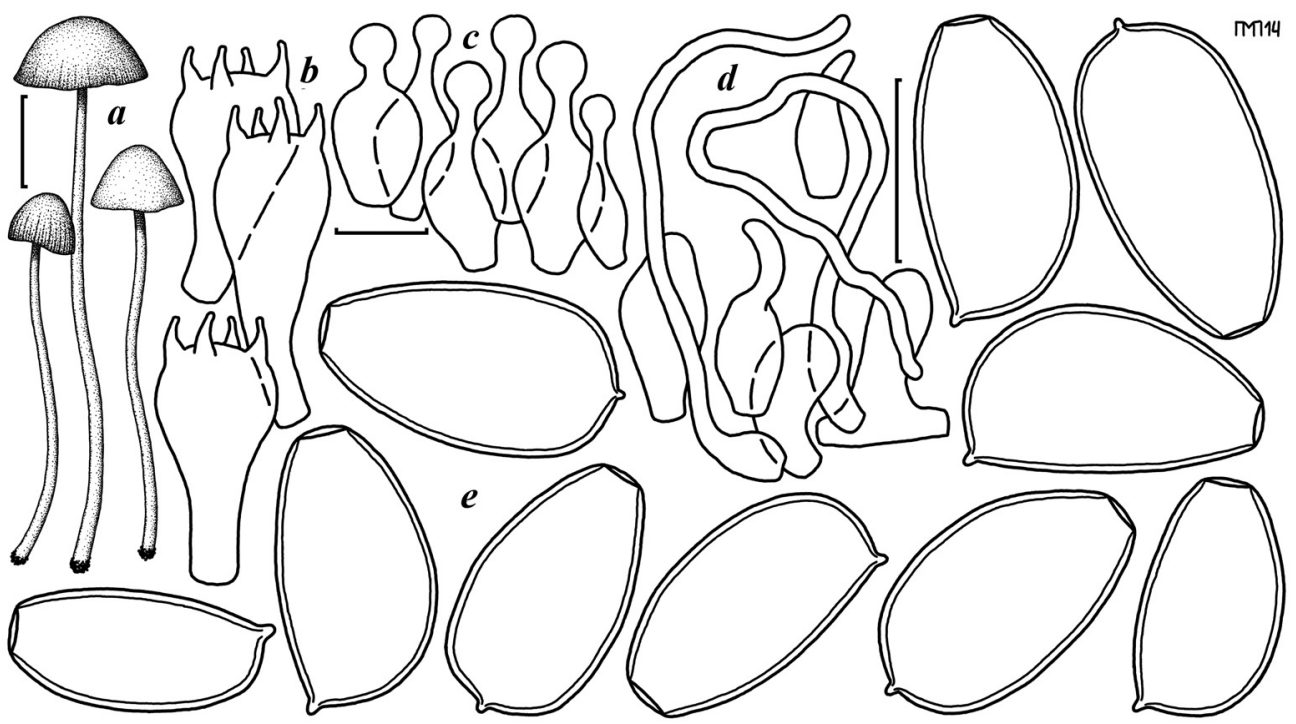

Fig. 12. Conocybe magnispora: $\mathbf{a}$ - fruit bodies, $\mathbf{b}$ - basidia, $\mathbf{c}$ - cheilocystidia, $\mathbf{d}$ - caulocystidia, e - spores. Bars: $10 \mathrm{~mm}$ for fruit bodies, $10 \mu \mathrm{m}$ for microstructures 
brownish orange to rust-brown, with concolorous finely flocculose edge. Stipe 15.0-25.0 × 1.0-1.5 mm, cylindrical with clavate base, hollow, slightly pruinose, later nearly glabrous, whitish, later pale yellowish to ochraceous. Flesh in pileus up to $0.5 \mathrm{~mm}$ wide, whitish to pale yellowish, in stipe pale ochraceous. Taste and smell indistinct. Spore-print light rustbrown.

Spores 12.5-17.0 $(-18.0) \times 8.0-10.5 \mu \mathrm{m}(\mathrm{n}=20), \mathrm{Q}=1.59-1.85$; av. $\mathrm{L}=15.3 \pm 1.16$ $\mu \mathrm{m}$, av. $\mathrm{B}=9.0 \pm 0.58 \mu \mathrm{m}$, av. $\mathrm{Q}=1.7 \pm 0.08$; in front view ovate, narrowly ovate and ellipsoid, in side view ellipsoid, somewhat flattened ventrallys or slightly amygdaliform, germ-pore up to $2.5 \mu \mathrm{m}$ wide, thick-walled, pale yellow-brown in water, orange-brown in alkali. Basidia 24.0-31.0 × 12.5-14.0 $\mu \mathrm{m}$, clavate, 4-spored. Cheilocystidia 18.0-22.0 × 6.0-10.5 $\mu \mathrm{m}$, lecythiform, neck up to $4.5 \times 2.5 \mu \mathrm{m}$, head 3.5-5.5 $\mu \mathrm{m}$ wide. Pleurocystidia absent. Pileocystidia not recorded. Caulocystidia of two types: a) 12.0-20.0 × 6.0-9.5 $\mu \mathrm{m}$, globose, globose-clavate, clavate, utriform and lageniform, numerous; b) hair-like, up to $70.0 \times 2.0$ $\mu \mathrm{m}$, scattered. Pileipellis hymeniform, cosisting of sphaeropedunculate and pyriform cells 12.0-28.0 $\mu \mathrm{m}$ wide. Clamp connections present. Ammoniacal reaction absent.

Habitat and distribution. Solitary and in small groups on dung (cow, horse), in forests and grasslands (meadows, pastures), in autumn. In Ukraine apprently rare. In Europe very rare, known also in Asia (India, Siberia), North and South America (Hausknect 2009).

Specimen examined: UKRAINE, CHERNIVTSI REGION, Vyzhnytsia district, Vyzhnytsia National Nature Park, environs of the village Mala Vyzhenka, 48 $11^{\prime}$ N, 25⒈ E, alt. ca 450 m, horse dung, 10 Sep 2013, M.P. Prydiuk (KW 50729).

Conocybe magnispora can be identified by rather small fruit bodies, very large thickwalled spores and 4-spored basidia. The most microscopically similar dung-inhabiting species is $C$. singeriana Hauskn. possessing, however, much larger basidiocarps (pileus $10.0-40.0 \mathrm{~mm}$ ) and stipe with distinctly bulbous base. Also growing on dung C. watlingii Hauskn. has rather similar spores but its fruit-bodies are distinctly darker, stipe with rootlike base and at stipe apex few lecythiform cystidia occur (Arnolds 2005; Hausknecht 2009).

\section{Series Siliginea}

Conocybe siliginea (Fr. : Fr.) Kühner, Genre Galera: 96, 1935; non sensu Singer, Acta Inst. Bot. Komarov Acad. Sci. USSR 2(6): 44, 1950 (= C. rickenii).

Fig. 13 Agaricus siligineus Fr., Observ. mycol. 2: 168, 1818. - Agaricus tener ("var.") siligineus Fr. : Fr., Syst. mycol. 1: 266, 1821. - Galera siliginea (Fr. : Fr.) Quél., Mém. Soc. Emul. Montbéliard, Sér. II, 5: 136, 1872; non sensu Ricken, Blätterpilze: 224, 1915 (= C. moseri). Non Conocybe siliginea f. typica 'récoltes tétrasporiques' sensu Kühner, Genre Galera: 108, 1935 (= C. moseri). - Non Conocybe siliginea f. typica 'récoltes bisporiques' sensu Kühner, Genre Galera: 109, 1935 (= C. bisporigera). - Non Conocybe siliginea 'forme tétrasporique' sensu Kühner \& Romagn., Fl. anal. Champ. sup.: 345, 1953 (= C. moseri).

Pileus $3.0-17.0 \mathrm{~mm}$, at first campanulate or conical, later campanulate-convex, conical-convex, hemispherical to convex, smooth, light brown, pale brown, ochraceous, somewhat darker at centre, hygrophanous, not translucently striate, on drying becoming pale ochraceous, cream or whitish, at centre ochraceous. Lamellae narrowly adnate or almost free, rather distant $(\mathrm{L}=20-25,1=1-3)$, ventricose, up to $2.0 \mathrm{~mm}$ wide, at first pale 


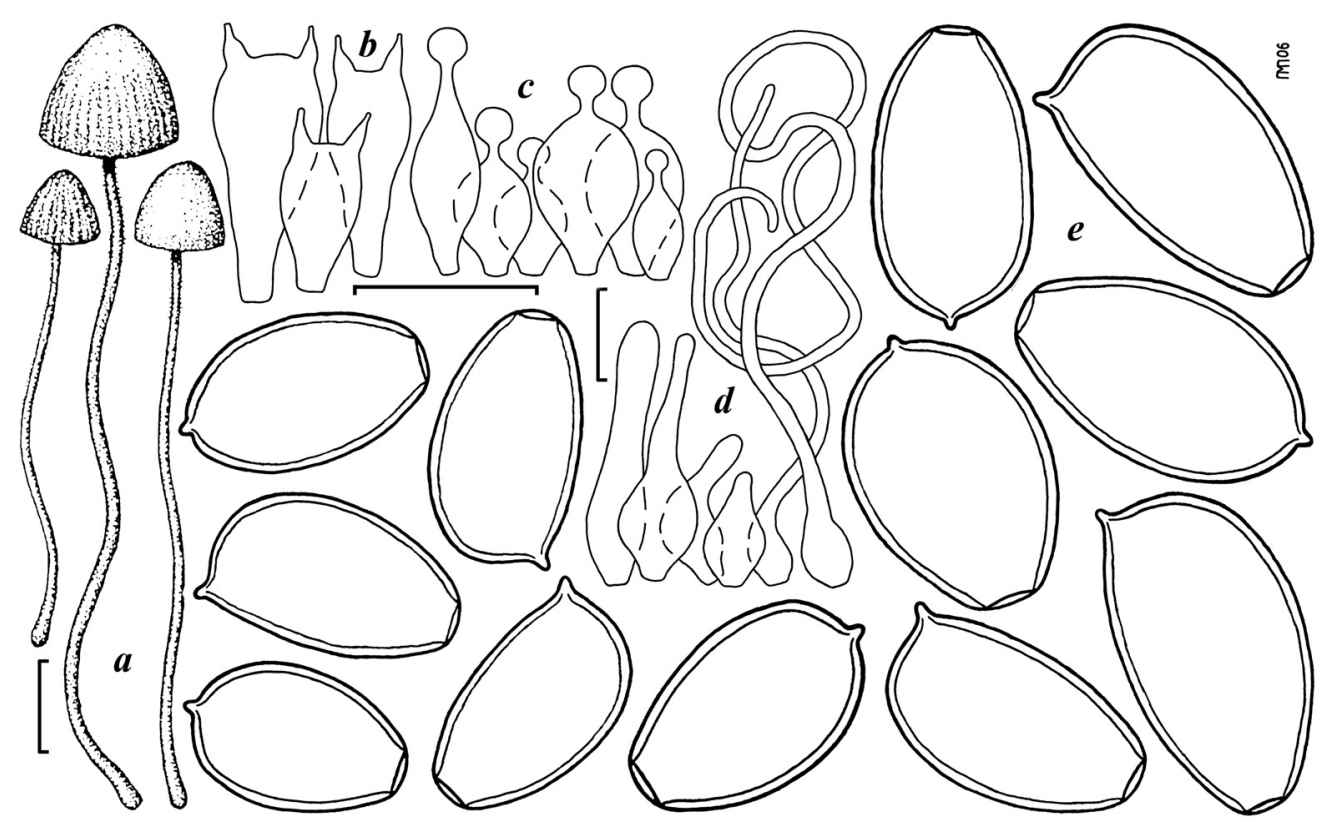

Fig. 13. Conocybe siliginea: a - fruit bodies, $\mathbf{b}$ - basidia, c - cheilocystidia, $\mathbf{d}$ - caulocystidia, e-spores. Bars: $10 \mathrm{~mm}$ for fruit bodies, $10 \mu \mathrm{m}$ for microstructures

ochraceous, later light yellow-brown to orange-brown, with paler finely flocculose edge. Stipe $20.0-95.0 \times 1.0-1.5 \mathrm{~mm}$, cylindrical with clavate, sometimes slightly swollen base, hollow, longitudinally pubescent-striate, at first white, later darkening from base upwards to whitish with brownish tinge or pale brown. Flesh in pileus up to $1.5 \mathrm{~mm}$ wide, whitish with ochraceous-brown hue, in stipe pale ochraceous-brown, at base brownish. Taste and smell indistinct. Spore-print rust-brown.

Spores (9.5-)12.0-16.5(-17.5) $\times(6.5-) 8.0-10.5(-11.0) \mu \mathrm{m}(\mathrm{n}=40), \mathrm{Q}=1.20$ 1.86; av. $\mathrm{L}=14.3 \pm 1.25 \mu \mathrm{m}$, av. $\mathrm{B}=9.0 \pm 0.69 \mu \mathrm{m}$, av. $\mathrm{Q}=1.59 \pm 0.1$; in front view ovate-ellipsoid, narrowly ellipsoid and ellipsoid, in side view ellipsoid, slightly flattened ventrally, sometimes somewhat amygdaliform, germ-pore 2.0-3.0 $\mu \mathrm{m}$ wide, thick-walled, light honey-brown in water, rust-brown or reddish brown in alkal. Basidia 14.5-36.0 $\times$ 8.0-12.0 $\mu \mathrm{m}$, clavate, 2-spored, sometimes 1-spored occur. Cheilocystidia 14.5-31.0 $\times$ 6.0-12.0 $\mu \mathrm{m}$, lecythiform, neck up to $4.0 \times 2.0 \mu \mathrm{m}$, head 3.0-4.5 $\mu \mathrm{m}$ wide. Pleurocystidia absent. Pileocystidia hair-like, up to $75.0 \times 2.5-3.5 \mu \mathrm{m}$, scattrerd to fairly numerous. Caulocystidia of two types: a) 7.0-31.0 × 3.5-9.5 $\mu \mathrm{m}$, ellipsoid, globose-clavate, clavate, cylindrical, utriform and lageniform, numerous; b) hair-like, up to $220.0 \times 1.5-2.0 \mu \mathrm{m}$, moderately numerous. Pileipellis hymeniform, consisting of sphaeropedunculate and pyriform cells $16.0-30.0 \mu \mathrm{m}$ wide. Clamp connections present. Ammoniacal reaction negative.

Habitat and distribution. Solitary or in small groups on soil, sometimes on manured soil or burnt places, usually in grasslands (meadows, pastures, roadsides, in steppes), sometimes 
in forests, spring-autumn. In Ukraine moderately widespread (Prydiuk 2007a). In Europe common, also known in Africa, Asia and North America (Hausknecht 2009).

Specimens examined: UKRAINE, CHERNIVTSI REGION, Vyzhnytsia district, Vyzhnytsia National Nature Park, environs of the town Beregomet, 4809' N, 2520' E, alt. ca 450 m, cow dung, 5 Sep 2013, M.P. Prydiuk (KW 50733); valley of the river Stebnyk, $48^{\circ} 11^{\prime}$ N, $25^{\circ} 19^{\prime}$ E, alt. ca 450 m, soil, 6 Sep 2013, M.P. Prydiuk (KW 50734).

Conocybe siliginea is very close to $C$. rickenii (Jul. Schäff.) Kühner, but has more slender and paler fruit bodies without any olivaceous hue. Besides, this species usually grows on soil, while C. rickenii prefers dung and compost (Hausknecht 2009).

Series Lenticulospora Hauskn. \& Krisai

Conocybe hexagonospora Hauskn. \& Enderle, in Hausknecht, Österr. Z. Pilzk. 2: 40, 1993.

Fig. 14 Conocybe hexagonospora Métrod, Bull. trimest. Soc. mycol. Fr. 56: 48, 1940 (nom. inval.).

Pileus 4.0-20.0 $\mathrm{mm}$, at first campanulate, later conical-campanulate, campanulateconvex, conical-convex to convex, slightly umbonate, smooth or slightly pubescent, orangebrownish, light ochraceous-brown, light yellowish brown or honey-brown, in centre darker, to rust-brown, hygrophanous, translucently striate up to $1 / 3$ radius and more, on drying becoming pale yellow or pale yellowish ochraceous. Lamellae narrowly adnate to almost free, moderately crowded to rather distant $(\mathrm{L}=20-27, \mathrm{l}=1-3(-7))$, ventricose, up to 3.0 $\mathrm{mm}$ wide, at first pale brown, later light brown to rust-brown, with paler finely flocculose edge. Stipe 30.0-75.0 × 1.0-2.0 mm, cylindrical with clavate base, hollow, slightly longitudinally pubescent-striate, at first white with brownish hue, later darkening from base upwards to cream, ochraceous or pale brown. Flesh in pileus up to $1.5 \mathrm{~mm}$ wide, whitish with ochraceous-brown tinge, in stipe darker, pale browhish, light brownish in base. Smell and taste indistinct. Spore-print rust-brown.

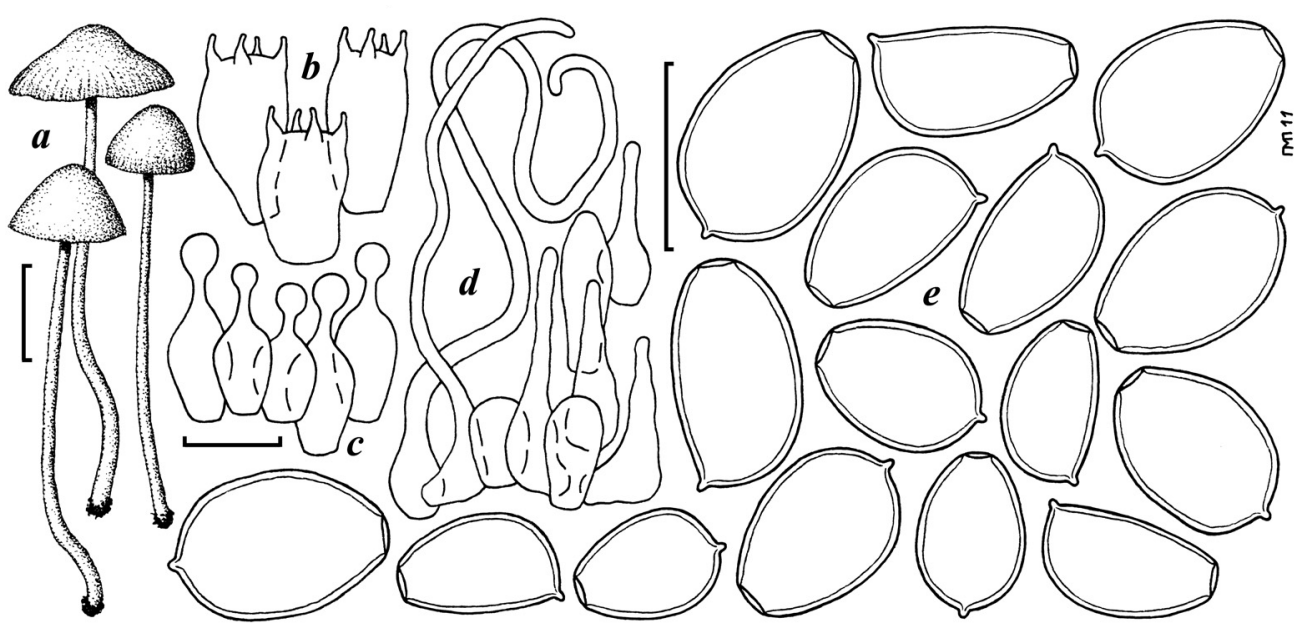

Fig. 14. Conocybe hexagonospora: $\mathbf{a}$ - fruit bodies, $\mathbf{b}$ - basidia, c - cheilocystidia, $\mathbf{d}$ - caulocystidia, e - spores. Bar: $10 \mathrm{~mm}$ for fruit bodies, $10 \mu \mathrm{m}$ for microstructures 
Spores 9.0-11.5 × 6.0-7.0 × 5.0-6.0 $\mu \mathrm{m}(\mathrm{n}=20), \mathrm{Q}=1.50-1.80 ; \mathrm{av} . \mathrm{L}=10.2 \pm 0.59$ $\mu \mathrm{m}$, av. $\mathrm{B}=6.3 \pm 0.30 \mu \mathrm{m}$, av. $\mathrm{Q}=1.60 \pm 0.08$; lentiform, in front view ovate, broadlyellipsoid, submitriform to slightly angulate, in side view ellipsoid, slightly flattened ventrally to slightly amygdaloid, germ-pore central, up to $1.0-1.5 \mu \mathrm{m}$ wide, rather thickwalled, in water light honey-brown, in alkali rust-brown or reddish brown. Basidia 14.5$19.0 \times 7.0-9.5 \mu \mathrm{m}$, clavate, 4-spored. Cheilocystidia 14.5-20.0 × 6.0-7.5 $\mu \mathrm{m}$, lecythiform, neck up to $3.0 \times 1.5 \mu \mathrm{m}$, head 3.0-4.0 $\mu \mathrm{m}$ wide. Pleurocystidia absent. Pileocystidia not observed. Caulocystidia of two types: a) globose-clavate, clavate and lageniform, 9.5-22.0 $\times 5.5-7.0 \mu \mathrm{m}$; b) hair-like, up to $85.0 \times 1.5-2.0 \mu \mathrm{m}$. Pileipellis hymeniform, consisting of spheropedunculate and pyriform elements 12.0-29.0 $\mu \mathrm{m}$ wide. Clamp connections present. Ammoniacal reaction negative.

Habitat and distribution. Solitary or in small groups on soil among moss in frondose and mixed forests, in autumn. In Ukraine apparently rare, earlier found in one location (Ternopil region). In Europe widespread in montane regions, known also from Asia (Hausknecht 2009).

Specimen examined: UKRAINE, CHERNIVTSI REGION, Vyzhnytsia district, Vyzhnytsia National Nature Park, valley of the river Stebnyk, $48^{\circ} 10^{\prime} \mathrm{N}, 25^{\circ} 17^{\prime} \mathrm{E}$, alt. ca 450 m, mossy soil, 8 Sep 2013, M.P. Prydiuk (KW 50724).

According to indications of Hausknecht (1993) the characteristic feature of $C$. hexagonospora is the presence of lentiform and slightly hexagonal spores in front view. Spores of similar shape are also known for C. lenticulospora Watling, which, however, grows on dung or manured soil and has much larger spores. Another species with subhexagonal spores is C. brunneidisca (Murrill) Hauskn., which differs by larger spores (9.0-13.0 × 6.5$9.0 \mu \mathrm{m}$ ) and growth on dung and manured soil (Enderle 1999; Hausknecht 2009). Also C. rostellata is similar in some aspects to $C$. hexagonospora but it differs by not lentiform and not angulate spores of slightly smaller size.

Up-to-date 33 species of the genus Conocybe (including those treated in this paper) are known in Ukraine. Taking into account, that in Europe about 100 species of the genus are known, one can expect some more interesting finds on the territory of Ukraine in future.

Acknowledgements. I am very thankful to Anton Hausknecht (Maissau, Austria) for his help and extensive advices, as well as Yu.Ya. Tykhonenko and V.P. Hayova (Kiev, Ukraine) for their corrections.

\section{References}

Arnolds, E. 2005. 2. Conocybe Fay. - In: M.E. Noordeloos, Th.W. Kuyper \& E.C. Vellinga (eds). Flora Agaricina Neerlandica. Vol. 6. Bolbitiaceae (Bolbitius, Conocybe, Pholiotina, Agrocybe) and Coprinaceae (I): the genus Coprinus. Pp. 120-179. Taylor \& Francis, Boca Raton, London, New York, Singapore. 
Besedina, I.S. 1998. [Summary of the species composition of agaricoid basidiomycetes of the Pridneprovskoj lowland (in the Left-Bank Forest-Steppe of Ukraine)]. Poltava National Pedagogical University, Poltava. (In Russian)

Bobyak, H. 1907. [Additions to the mycology of eastern Halychyna. Fungi of surroundings of Berezhany]. Zbirnyk Matematychno-Prirodopisno-Likarskoi Sektsyi Naukovoho Tovaristva Shevchenka 11: 1-40. (In Ukrainian)

Chorney, I.I., Budzhak, V.V., Yakishenko, D.M., Korzhyk, V.P., Solomakha, V.A., Sorokan, Yu.I., Tokariuk, A.I. \& Solomakha, T.D. 2005. [Vyzhnytsia National Nature Park. Plant world]. Fitosociocentr, Kyiv. (In Ukrainian)

Enderle, M. 1991. Conocybe-Pholiotina Studien I: Bestimmungsschlüssel für europäische Arten der Gattung Conocybe Fayod. - Zeitschrift für Mykologie 57: 55-74.

Enderle, M. 1999. Conocybe-Pholiotina-Studien IX. - Beiträge zur Kenntnis der Pilze Mitteleuropas XII: 75-84.

Ganzha, R.V. 1960a. [Mushrooms of the order Agaricales of the mixed forests over the Vorskla]. - Ukrainian Botanical Journal 27(5): 72-84. (In Ukrainian)

Ganzha, R.V. 1960b. [Cap mushrooms of oak forests of the valley of the river Vorskla]. - Botanical Journal 45(5): 758-764. (In Russian)

Gizhytska, Z.G. 1929. [Material to the mycological flora of the Ukraine]. - Bulletin Kiev Botanical Garden 10: 4-41. (In Ukrainian)

Hausknecht, A. 1993. Beiträge zur Kenntniss der Bolbitiaceae 1. Pholiotina subnuda und Conocybe hexagonospora. - Österreichische Zeitschrift für Pilzkunde 2: 33-43.

Hausknecht, A. 1999. Beiträge zur Kenntniss der Bolbitiaceae 5. Die Conocybe rickeniana- und C. magnicapitata-Gruppe in Europa. - Österreichische Zeitschrift für Pilzkunde 8: 35-61.

Hausknecht, A. 2000. Beiträge zur Kenntniss der Bolbitiaceae 6. Die Conocybe tenera-Gruppe in Europa, Teil 1. - Österreichische Zeitschrift für Pilzkunde 9: 73-109.

Hausknecht, A. 2003. Beiträge zur Kenntniss der Bolbitiaceae 9. Conocybe sect. Mixtae. - Österreichische Zeitschrift für Pilzkunde 12: 41-83.

Hausknecht, A. 2009. A monograph of the genera Conocybe Fayod and Pholiotina Fayod in Europe. Edizioni Candusso, Alassio.

Hausknecht, A. \& Krisai-Greilhuber, I. 2006. Infragenetic division of the genus Conocybe - a classical approach. - Österreichische Zeitschrift für Pilzkunde 15: 187-212.

Pilát, A. 1940. Hymenomycetes Carpatorum orientalium. - Sborník Národního Musea v Praze 2.B(3): 37-80.

Prydiuk, M.P. 2003. [Rare macromycetes (Agaricaceae, Bolbitiaceae) from the Crimean nature reserve].Ukrainian Botanical Journal 60(3): 305-313. (In Ukrainian)

Prydiuk, M.P. 2005. [Basidial macromycetes of the Luhansk nature reserve]. - Collection of Scientific Works of Luhansk NAU, Series Biological Sciences 56(79): 69-92. (In Ukrainian)

Prydiuk, M.P. 2007a. New records of Conocybe species from Ukraine. I. The sections Mixtae and Pilosellae.Czech Mycology 59: 25-38.

Prydiuk, M.P. 2007b. New records of Conocybe species from Ukraine. II. The section Conocybe. - Czech Mycology 59: 39-50.

Wasser, S.P. 1973. [The flora of Agaricales of virgin steppe of the Ukraine]. - Ukrainian Botanical Journal 30(4): 457-467. (In Ukrainian) 
Wasser, S.P. 1974. [Cap mushrooms (orders Boletales, Agaricales, Russulales) of the natural forests of the Ukraine. II. Mushrooms of the long- and short-flooded forests]. - Ukrainian Botanical Journal 31(4): 440-445. (In Ukrainian)

Wasser, S.P. \& Soldatova, I.M. 1977. [Higher Basidiomycetes of Steppe zone of Ukraine]. Naukova Dumka, Kiev. (In Russian) 